\title{
Winter and summer nitrous oxide and nitrogen oxides fluxes from a seasonally snow-covered subalpine meadow at Niwot Ridge, Colorado
}

\author{
Gianluca Filippa · Michele Freppaz • \\ Mark W. Williams · Detlev Helmig · Daniel Liptzin • \\ Brian Seok · Brad Hall $\cdot$ Kurt Chowanski
}

Received: 15 September 2008/Accepted: 24 February 2009/Published online: 6 May 2009

(C) The Author(s) 2009. This article is published with open access at Springerlink.com

\begin{abstract}
The soil emission rates (fluxes) of nitrous oxide $\left(\mathrm{N}_{2} \mathrm{O}\right)$ and nitrogen oxides $\left(\mathrm{NO}+\mathrm{NO}_{2}=\right.$ $\mathrm{NO}_{x}$ ) through a seasonal snowpack were determined by a flux gradient method from near-continuous 2-year measurements using an automated system for sampling interstitial air at various heights within the snowpack from a subalpine site at Niwot Ridge,
\end{abstract}

G. Filippa $(\varangle) \cdot$ M. Freppaz

Di.Va.P.R.A. (Dipartimento di Valorizzazione e

Protezione delle Risorse Agroforestali) Chimica Agraria e

Pedologia, Università degli Studi di Torino, via L. Da

Vinci 44, Grugliasco (TO) 10095, Italy

e-mail: gianluca.filippa@unito.it

M. W. Williams

Department of Geography, University of Colorado, Boulder, CO, USA

M. W. Williams · D. Helmig · D. Liptzin ·

B. Seok $\cdot$ K. Chowanski

Institute of Arctic and Alpine Research, University of Colorado, Boulder, CO, USA

\section{Liptzin}

Department of Environmental Science, Policy, \& Management, University of California at Berkeley, Berkeley, CA, USA

\section{B. Seok}

Department of Atmospheric and Oceanic Sciences, University of Colorado, Boulder, CO, USA

B. Hall

Earth System Research Laboratory, National Oceanic and Atmospheric Administration, Boulder, CO, USA
Colorado. The winter seasonal-averaged $\mathrm{N}_{2} \mathrm{O}$ fluxes of $\quad 0.047-0.069 \mathrm{nmol} \mathrm{m}^{-2} \mathrm{~s}^{-1}$ were $\sim 15$ times higher than observed $\mathrm{NO}_{x}$ fluxes of 0.0030 $0.0067 \mathrm{nmol} \mathrm{m}^{-2} \mathrm{~s}^{-1}$. During spring $\mathrm{N}_{2} \mathrm{O}$ emissions first peaked and then dropped sharply as the soil water content increased from the release of snowpack meltwater, while other gases, including $\mathrm{NO}_{x}$ and $\mathrm{CO}_{2}$ did not show this behavior. To compare and contrast the winter fluxes with snow-free conditions, $\mathrm{N}_{2} \mathrm{O}$ fluxes were also measured at the same site in the summers of 2006 and 2007 using a closed soil chamber method. Summer $\mathrm{N}_{2} \mathrm{O}$ fluxes followed a decreasing trend during the dry-out period after snowmelt, interrupted by higher values related to precipitation events. These peaks were up to 2-3 times higher than the background summer levels. The integrated $\mathrm{N}_{2} \mathrm{O}-\mathrm{N}$ loss over the summer period was calculated to be $1.1-2.4 \mathrm{~kg} \mathrm{~N} \mathrm{ha}^{-1}$, compared to $\sim 0.24-0.34 \mathrm{~kg} \mathrm{~N} \mathrm{ha}^{-1}$ for the winter season. These wintertime $\mathrm{N}_{2} \mathrm{O}$ fluxes from subniveal soil are generally higher than the few previously published data. These results are of the same order of magnitude as data from more productive ecosystems such as fertilized grasslands and high-N-cycling forests, most likely because of a combination of the relatively welldeveloped soils and the fact that subnivean biogeochemical processes are promoted by the deep, insulating snowpack. Hence, microbially mediated oxidized nitrogen emissions occurring during the winter can be a significant part of the N-cycle in seasonally snow-covered subalpine ecosystems. 
Keywords Denitrification - Nitrification ·

Nitrogen oxides · Nitrous oxide - Snowpack ·

Soil biogeochemistry

\section{Introduction}

Nitrous oxide $\left(\mathrm{N}_{2} \mathrm{O}\right)$ and nitrogen oxides $(\mathrm{NO}+\mathrm{N}$ $\mathrm{O}_{2}=\mathrm{NO}_{X}$ ) are oxidized nitrogen $(\mathrm{N})$ compounds produced by soils from microbially mediated processes. In recent decades the atmospheric concentration of $\mathrm{N}_{2} \mathrm{O}$ has increased due to anthropogenic activity, becoming a concern with regard to global warming (IPCC 2001). $\mathrm{N}_{2} \mathrm{O}$ emissions from soils are a significant part of the global $\mathrm{N}$ cycle, contributing $58 \%$ of the total global $\mathrm{N}_{2} \mathrm{O}-\mathrm{N}$ emission rate on a yearly basis; with more than half of the $\mathrm{N}_{2} \mathrm{O}$ emitted from non-agricultural ecosystems (IPCC 2001). In contrast, the main sources of $\mathrm{NO}_{x}$ are combustion processes, while soils are responsible for between 10 and $23 \%$ of the total $\mathrm{NO}_{x}$ emissions, with slightly less than half of this fraction emitted by agricultural, fertilized soils (Delmas et al. 1997). $\mathrm{NO}_{x}$ emissions can play a significant role in the tropospheric oxidation chemistry, and affect the formation and increase in tropospheric ozone, and thereby, similarly as $\mathrm{N}_{2} \mathrm{O}$, contributing to the greenhouse gas effect.

$\mathrm{N}$ gaseous fluxes from soils have been well characterized during the growing season (Bowden 1986; Dunfield et al. 1995; Smith et al. 1998). In contrast, over-winter emission rates in seasonally snow-covered catchments have been poorly assessed, although there is evidence that microbial activity and consequent emission of gaseous $\mathrm{C}$ and $\mathrm{N}$ continue in the relatively warm conditions that may occur in soils under a continuous snowpack (Sommerfeld et al. 1993; Brooks et al. 1996; Schürmann et al. 2002). Most over-winter investigations of emissions of $\mathrm{N}$ gases have been conducted in agricultural (van Bochove et al. 1996; Mosier et al. 1997; Maljanen et al. 2007) and organic soils (Alm et al. 1999; Maljanen et al. 2003) or lower-elevation forested areas (Groffman et al. 2006), with relatively few studies conducted in high-elevation mountain ecosystems (Brooks et al. 1996). While substantial work has been done on wintertime oxidized carbon (i.e.,
$\mathrm{CO}_{2}$ ) emissions in such ecosystems (Monson et al. 2006a, b; Jones et al. 1999; Liptzin et al. 2009), it is poorly known how these findings relate to oxidized $\mathrm{N}$ compounds (Schürmann et al. 2002). Moreover, it is not well established how changes in climate, and changes in the insulating snow cover affect the fluxes of oxidized $\mathrm{N}$ compounds in mountainous, nonagricultural soils.

Gaseous soil fluxes have been commonly measured by the chamber technique (e.g., Martikainen et al. 1993; Alm et al. 1999). During winter chamber measurements may cause sampling problems by changing the snow properties and soil insulation inside the enclosure from the experiment. Additionally, chamber measurements are time consuming and provide a discontinuous dataset. A further concern is how deep chamber walls should be placed in a porous media, such as snow, to realize a closed chamber design.

Here we conducted continuous sampling of air from inside a deep snowpack and determined vertical $\mathrm{N}_{2} \mathrm{O}$ and $\mathrm{NO}_{x}$ concentration profiles in the snowcovered seasons of 2006 (late fall 2005 to late spring 2006, hereafter referred to as winter 2006) and 2007 (late fall 2006 to late spring 2007, hereafter referred to as winter 2007) in a subalpine meadow soil in the Colorado Rocky Mountains. We then applied Fick's law to calculate diffusional fluxes from these gradient data. These winter measurements are contrasted to the snow-free period (i.e., summers 2006 and 2007) when $\mathrm{N}_{2} \mathrm{O}$ fluxes were measured approximately weekly using a closed soil chamber technique. Moreover, concomitant measurements of $\mathrm{CO}_{2}$ efflux during the same experiments (Liptzin et al. 2009) allow us to evaluate the relationships among these gases.

The resulting data are used to:

(1) Estimate the $\mathrm{N}_{2} \mathrm{O}$ flux during the snow-covered season and compare it to the summer flux, to assess an annual budget;

(2) Evaluate total oxidized $\mathrm{N}$ emissions and test if $\mathrm{NO}_{x}$ winter fluxes are a significant loss of $\mathrm{N}$ for this ecosystem;

(3) Evaluate the seasonal and inter-year variability of $\mathrm{N}_{2} \mathrm{O}$ and $\mathrm{NO}_{x}$ fluxes;

(4) Investigate environmental parameters controlling $\mathrm{N}_{2} \mathrm{O}$ and $\mathrm{NO}_{x}$ export from this ecosystem during both winter and summer periods. 


\section{Materials and methods}

Description of the study site

This research was conducted on Niwot Ridge, Colorado $\left(40^{\circ} 02^{\prime} 52^{\prime \prime} \mathrm{N} ; 105^{\circ} 34^{\prime} 15^{\prime \prime} \mathrm{W}, 3,345 \mathrm{~m}\right.$ a.s.1.). This site is a subalpine open meadow surrounded by ribbon forest, on a $10^{\circ} \mathrm{SW}$ slope.

Soil is classified as a mixed Typic Humicryept, sandy-skeletal in texture. Soil $\mathrm{pH}$ ranges from 4.6 to 5.0 (Fisk and Schmidt 1995). The organic carbon in the A horizon ranges from 150 to $190 \mathrm{~g} \mathrm{~kg}^{-1}$ and $\mathrm{N}$ ranges from 11 to $22 \mathrm{~g} \mathrm{~kg}^{-1}$ (Burns 1980; Brooks et al. 1995). The climate is characterized by a long (6-7 months), cold winter and a short, cool growing season. Mean annual temperature is $-3.7^{\circ} \mathrm{C}$, annual precipitation is $1,050 \mathrm{~mm}, 80 \%$ of which falls as snow (Caine 1995).

Snowpack gradient sampling method

The snowpack flux experiments were performed using a multi-level gradient tower. This tower was installed at the site before the onset of the snow accumulation season and allowed to be covered by the precipitating snow without any disturbance throughout the snow-covered time period. In winter 2006, the snow tower consisted of five paired inlets at $0,30,60,90$ and $245 \mathrm{~cm}$ above the soil surface. In 2007 , three new inlets heights were added resulting in paired inlets located at $0,10,30,60,90,120,150$, and $245 \mathrm{~cm}$ above the soil surface, with the latter inlet remaining above the maximum snowpack height throughout the winter season and representing ambient atmospheric conditions.

Sampling lines were all perfluoroalkoxy (PFA) Teflon $^{\circledR}$, inner diameter of $3.9 \mathrm{~mm}$ and outer diameter of $6.4 \mathrm{~mm}$ (Parker Hannifin, Cleveland, Ohio, USA), with equal lengths of $18 \mathrm{~m}$. The inlets were fitted with $25-\mathrm{mm}$ Acrodisc ${ }^{\circledR}$ hydrophobic polytetrafluoroethylene (PTFE) syringe filters (Pall Life Sciences, Ann Arbor, Michigan, USA) to prevent debris from entering the sampling line. Prior to field installation inlet filters and sampling lines were conditioned for $>24 \mathrm{~h}$ in a $\sim 11$ flow of 200 $300 \mathrm{ppbv}$ of ozone in room air. Sampling was done by drawing air sequentially from each inlet height for $10 \mathrm{~min}$, resulting in an 80-min cycle time. Air delivery from the snow inlets was provided by the combined flow rates of the pumps in the nitrogen oxides and ozone analyzers $\left(\sim 2.8 \mathrm{~L} \mathrm{~min}^{-1}\right)$, with the $\mathrm{N}_{2} \mathrm{O}$ gas chromatography (GC) system pulling another small fraction $\left(45 \mathrm{~mL} \mathrm{~min}^{-1}\right)$ from this manifold. Seok et al. (2009) and Bowling et al. (2009) report that active pumping of the air from the snowpack at this rate did not result in any significant artifact from the ventilation induced by the air sampling flow, because collected gas volumes were relatively small and the time lag between subsequent samplings was long enough to re-equilibrate gas levels in the snowpack.

\section{$\mathrm{N}_{2} \mathrm{O}$ data}

For the 2006 winter, vertical profile data are available from day of year (DOY) 30 to 49, 52 to 82,85 to 108 , 129 to 136, from four inlet heights sampling interstitial air in the snowpack (i.e., 90, 60, 30 and $0 \mathrm{~cm}$ ), and one inlet sampling atmospheric air $(245 \mathrm{~cm})$, summing a total of 86 days sampled and $\sim 1,235$ profiles. For the 2007 winter, vertical profile data are available from DOY 29 to 47,51 to 61,93 to 101,112 to 114,116 to 130,137 to 149 , from seven inlets in the snowpack (i.e. $150,120,90,60,30,10,0 \mathrm{~cm}$ ), and one inlet sampling atmospheric air $(245 \mathrm{~cm})$, summing a total of 68 days sampled and $\sim 1,000$ profiles.

$N O_{x}$ data

For the 2006 winter, a dataset of vertical profile concentrations is available from DOY (2006) -46 to 1,30 to 49,52 to 82,85 to 136 , from four different inlets sampling interstitial air in the snowpack (i.e., $90,60,30$ and $0 \mathrm{~cm}$ ), and one inlet sampling atmospheric air $(245 \mathrm{~cm})$, summing a total of 148 days and approximately 2,500 profiles sampled. In winter 2007, data are available from DOY (2007) -32 to 82,86 to 97,99 to 101,112 to 114,116 to 130 , from seven inlets in the snowpack (i.e., 150, 120, 90, $60,30,10,0 \mathrm{~cm}$ ), and one inlet sampling atmospheric air $(245 \mathrm{~cm})$, summing a total of 161 days and approximately 2,700 profiles sampled.

All instruments were fully automated, remained at the site, and were operated throughout the winters of 2006 and 2007. Site visits occurred typically once a week. Gaps in both the $\mathrm{NO}_{x}$ and $\mathrm{N}_{2} \mathrm{O}$ records resulted from occasional technical problems in the data logging or instrument operation. 
$\mathrm{N}_{2} \mathrm{O}$ measurement method

$\mathrm{N}_{2} \mathrm{O}$ was measured by a gas chromatograph (GC) equipped with an electron capture detector (ECD) (Shimadzu GC-8AIE, Shimadzu Scientific Instruments, Columbia, Maryland, USA). Air samples drawn from the snowpack first passed through a scrubber $(1.59 \mathrm{~cm}$ i.d., $1.90 \mathrm{~cm} \quad$ o.d., $15.24 \mathrm{~cm}$ length) filled with 20-30 g Ascarite (20-30 mesh) to remove the elevated and highly variable $\mathrm{CO}_{2}$ in the air sampled from the snowpack tower. The scrubber was refilled with fresh material every 7-14 days. A 9 ml-sample loop, connected to an electrically actuated 2-position, 10-port gas switching valve (Model E60, VICI, Huston, Texas, USA) was used for sample injection onto the GC column, which consisted of two sections of $3.18 \mathrm{~mm}$ o.d. and $3.67 \mathrm{~m}$ length stainless steel tubing packed with Porapak Q (Supleco, SigmaAldrich, St. Louis, Missouri, USA). The plumbing of the system allowed for the timed backflushing of the first column in order to avoid elution of water onto the second column and ECD detector. The carrier gas flow was $45 \mathrm{~mL} \mathrm{~min}^{-1}$ of a $95 \%$ argon, $5 \%$ methane mixture (AirGas Intermountain, Boulder, Colorado, USA). The GC oven was operated isothermally at $75^{\circ} \mathrm{C}$, and the detector temperature was $330^{\circ} \mathrm{C}$. The system was fully automated and computer-controlled. Every night a multipoint calibration was done to determine the ECD response and for tracking instrument drifts. Calibration standards were prepared gravimetrically at 320, 408, 485 ppbv (estimated uncertainty $0.1 \%$ ). The sample loop pressure was recorded for each sample and calibration run, and determined peak areas were corrected for the $\sim 0.9 \%$ variability $(1 \sigma)$ seen in the injection loop pressure during collection of samples from the different inlets and the standards. A first order regression equation was fit through the calibration data and used for quantification of $\mathrm{N}_{2} \mathrm{O}$ in samples. As $\mathrm{N}_{2} \mathrm{O}$ concentration in the snowpack air samples during the peak of the snowpack height exceeded the calibration range by up to $200 \%$, increasingly larger uncertainties in the $\mathrm{N}_{2} \mathrm{O}$ quantification are expected at these higher concentrations. After conclusion of the 2007 experiment we discovered a diurnal cycle/shift in the retention time and signal area of the $\mathrm{N}_{2} \mathrm{O}$ peak. This effect was traced to diurnal changes in the carrier gas cylinder temperature and regulator pressure (which were placed outside the underground laboratory, partially exposed to solar radiation). A series of further standard experiments was conducted to determine an algorithm that allowed applying a peak area correction based on the recorded retention time ( $r^{2}=0.98, p<0.001, n=144$, data not shown).

The precison of the GC measurement was estimated as $\sim 2 \%$ ( $\sim 6 \mathrm{ppbv})$, resulting in a sensitivity for the lowest measurable $\mathrm{N}_{2} \mathrm{O}$ gradient of $\sim 10$ ppbv. In addition, the sensitivity in flux determination is a function of other parameters that go into the diffusion calculation, and these in turn depend on snowpack physical properties. Based on the range of conditions encountered in both winters, the sensitivity (lowest measurable flux) was estimated to be on the order of $0.012 \mathrm{nmol} \mathrm{m}^{-2} \mathrm{~s}^{-1}$.

\section{$\mathrm{NO} / \mathrm{NO}_{2}$ measurement method}

$\mathrm{NO}_{x}$ concentrations were measured using a commercial chemiluminescence $\mathrm{NO}_{x}$ analyzer (Model 42CTL, Thermo Environmental Instruments, Franklin, Massachusetts, USA), with automated, multipoint calibrations performed nightly in a similar manner as for $\mathrm{N}_{2} \mathrm{O}$. The $\mathrm{NO}_{x}$ analyzer sensitivity is given as 50 pptv. Here, in order to estimate the lowest measurable $\mathrm{NO}_{x}$ flux we used a more conservative value of $\sim 1 \mathrm{ppbv}$ for the lowest detectable gradients (from two height measurements, with data acquisition over $10 \mathrm{~min}$ ). The lowest discernable flux was calculated as for $\mathrm{N}_{2} \mathrm{O}$, and was found to be $\sim 0.001 \mathrm{nmol} \mathrm{m}^{-2} \mathrm{~s}^{-1}$.

\section{Environmental parameters}

Air, snow and soil temperatures, atmospheric pressure, precipitation and a set of environmental parameters were recorded during both years of investigation. Volumetric soil moisture was determined for the 2007 winter at an integrated depth of 0-30 cm, using four CS616-L Water Content Reflectometers with $30-\mathrm{cm}$ long probes installed vertically into the soil in a $1-\mathrm{m}$ radius from the snow tower (Campbell Scientific, Logan, Utah, USA), with the average of the four sensors used for all further data applications. Temperatures at each of the gas sampling inlets were measured using type-E thermocouples (Omega Engineering, Inc., Stamford, Connecticut, USA) and were used in Eq. 2. The 0-cm-inlet level measurement was also used as the estimate of the temperature at the 
snow-soil interface. Each thermocouple was covered by white shrink tubing to reduce radiation artifacts. Barometric pressure included in Eq. 2 was measured using a CS105 Vaisala PTB101B Barometer (Campbell Scientific, Logan, Utah, USA) at a meteorological tower $10 \mathrm{~m}$ away from the snow flux tower.

Winter flux measurements and calculations

Winter fluxes were measured using the vertical $\mathrm{N}_{2} \mathrm{O}$ concentration profiles based on Fick's law,

$J_{\mathrm{N}_{2} \mathrm{O}}=-D_{\mathrm{N}_{2} \mathrm{O}}\left(\mathrm{d} C_{\mathrm{N}_{2} \mathrm{O}} / \mathrm{d} z\right)$

where $\left(\mathrm{d} C_{\mathrm{N}_{2} \mathrm{O}} / \mathrm{d} z\right)$ is the concentration gradient (nmol m $\mathrm{m}^{-3} \mathrm{~m}^{-1}$ ) and $D_{\mathrm{N}_{2} \mathrm{O}}$ is the gas diffusivity $\left(\mathrm{m}^{2} \mathrm{~s}^{-1}\right)$, calculated as follows:

$D_{\mathrm{N}_{2} \mathrm{O}}=\Phi \tau D_{\mathrm{STP}}\left(P_{0} / P\right)\left(T / T_{0}\right)^{\alpha}$

where $D_{\mathrm{STP}}=0.1436 \times 10^{-4} \mathrm{~m}^{2} \mathrm{~s}^{-1} \quad$ (Massman $1998)$ is the gas diffusivity at standard temperature and pressure, $\alpha=1.81$ (Massman 1998), $\tau$ is the snowpack tortuosity, and $\Phi$ is the snowpack porosity. The same procedure was used to calculate $\mathrm{NO}_{x}$ fluxes, assuming a diffusivity $D_{\mathrm{STP}}$ of $0.1361 \times$ $10^{-4} \mathrm{~m}^{2} \mathrm{~s}^{-1}$ and $0.1802 \times 10^{-4} \mathrm{~m}^{2} \mathrm{~s}^{-1}$ for $\mathrm{NO}_{2}$ and NO, respectively (Massman 1998).

The porosity and the tortuosity of the snowpack were both estimated from the snow density:

$\Phi=1-\left(\rho_{\text {snow }} / \rho_{\text {ice }}\right)$

$\tau=\Phi^{1 / 3}$

where $\rho_{\text {snow }}$ is the snow density $\left(\mathrm{kg} \mathrm{m}^{-3}\right)$ and $\rho_{\text {ice }}$ is the density of ice $\left(917 \mathrm{~kg} \mathrm{~m}^{-3}\right)$.

Snow density was measured at $10-\mathrm{cm}$ height intervals in the snowpack $\sim$ bi-weekly by digging a snowpit about $\sim 30 \mathrm{~m}$ away from the snow flux tower at a location with similar vegetation and slope characteristics, following the protocol of Williams et al. (1996). During the 2-year experiment, corrected $D_{\mathrm{N}_{2} \mathrm{O}}$ values ranged between $0.072 \times 10^{-4}$ and $0.140 \times 10^{-4} \mathrm{~m}^{2} \mathrm{~s}^{-1}$.

Summer flux measurements and calculations

Summer fluxes were determined using gas measurements from five closed, dark, vented chambers (i.d. $0.37 \mathrm{~m}$ i.d., $0.20 \mathrm{~m}$ height, $0.110 \mathrm{~m}^{2}$ area, $0.022 \mathrm{~m}^{3}$ volume). The chambers were located approximately $5 \mathrm{~m}$ away from the winter snow flux tower, and within $30 \mathrm{~cm}$ of each other. At each sampling date the order of measurement was randomly assigned in order to avoid systematic over or under-estimation of fluxes due to the diurnal flux fluctuation. Air in the headspace of each chamber was typically sampled every $10 \mathrm{~min}$ over 40-70 min of measurements, using a polypropylene $20 \mathrm{~mL}$ syringe. The lid of the chamber was equipped with a narrow tube for pressure equilibration (Welles et al. 2001). Fluxes were calculated by integrating $\mathrm{N}_{2} \mathrm{O}$ concentrations over time, using a Michaelis-Menten fitting curve (Welles et al. 2001), following the equation:

$J_{\mathrm{N}_{2} \mathrm{O}}=V / A \times \rho \times\left(\mathrm{d} C_{\mathrm{N}_{2} \mathrm{O}} / \mathrm{d} t\right)$

where $J_{\mathrm{N}_{2} \mathrm{O}}$ is the gas flux, $V$ and $A$ are the volume and the surface area of the chamber, respectively, $\rho$ $\left.(\mathrm{mol} \mathrm{m})^{-3}\right)$ is the molar concentration of air corrected for ambient pressure and temperature, and $\left(\mathrm{d} C_{\mathrm{N}_{2} \mathrm{O}} / \mathrm{d} t\right)$ is the concentration change with time $\left(\mathrm{nmol} \mathrm{mol}{ }^{-1} \mathrm{~s}^{-1}\right)$, which is obtained from:

$\mathrm{d} C_{\mathrm{N}_{2} \mathrm{O}} / \mathrm{d} t=k \times\left(C_{\mathrm{S}}-C_{0}\right)$

where $C_{0}$ is the ambient $\mathrm{N}_{2} \mathrm{O}$ concentration (nmol $\left.\mathrm{mol}^{-1}\right), k\left(\mathrm{~s}^{-1}\right) . C_{\mathrm{S}}\left(\mathrm{nmol} \mathrm{mol}{ }^{-1}\right)$ (the estimated concentration of $\mathrm{N}_{2} \mathrm{O}$ in soil) was calculated from an exponential fitting curve using the simplified model proposed by Welles et al. (2001). We used this approach to integrate fluxes because it appears more physically correct compared to traditional linear fitting (Welles et al. 2001).

In summer 2006, chamber measurements were carried out every 7-15 days (eight sampling days total), while in summer 2007 measurements occurred approximately twice a week (17 days of experiments). $\mathrm{NO}_{x}$ emissions were not measured from the chamber experiments.

\section{Soil analyses}

Topsoil $(0-10 \mathrm{~cm})$ was sampled weekly during summer 2007 in a $10 \mathrm{~m}^{2}$ subplot $\sim 10 \mathrm{~m}$ away from the snow flux tower, Per each date a representative sample of the whole plot was generated from 5 subsamples. Soil samples were processed within $24 \mathrm{~h}$ of returning from the field. Fresh soils were sieved and homogenized using a 2-mm sieve. The 5 subsamples were then extracted with $0.5 \mathrm{M} \mathrm{K}_{2} \mathrm{SO}_{4}$ 
(1:5 weight:volume) by shaking for $1 \mathrm{~h}$. Samples were then filtered through Whatman \#1 filter papers. Before extraction, each sample was divided in two subsamples, one was extracted and one fumigated for $18 \mathrm{~h}$ with chloroform and subsequently extracted as explained before. Extractable ammonium $\left(\mathrm{NH}_{4}{ }^{+}\right)$and nitrate $\left(\mathrm{NO}_{3}{ }^{-}\right)$were determined using a Spectrophotometric Analyzer (OI Analytical Flow Solution IV). $\mathrm{NH}_{4}{ }^{+}$determination was based on Berthelot reaction, while nitrate was reduced to nitrite on a cadmium column, and the resulting $\left(\mathrm{NO}_{3}{ }^{-}+\mathrm{NO}_{2}{ }^{-}\right)$were determined by diazotizing with sulfanilamide, followed by coupling with N-(1-naphthyl) ethylenediamine dihydrochloride. Total dissolved nitrogen (TDN) was determined as nitrate after digestion and oxidation with alkaline potassium persulfate. Dissolved organic nitrogen (DON) was calculated by the difference between TDN and inorganic $\mathrm{N}$ (i.e., $\mathrm{NH}_{4}{ }^{+}$ and $\left.\mathrm{NO}_{3}{ }^{-}\right)$. The microbial $\mathrm{N}\left(\mathrm{N}_{\text {microbial }}\right)$ was calculated by difference between the TDN of the fumigated samples and the TDN of the control samples. The resulting data were then corrected by a recovery factor of 0.54 (Brookes et al. 1985).

\section{Statistical analyses}

For the winter experiment, each 80-min cycle gradient data were used to calculate "hourly" fluxes (17 per day) from all combination of inlets. Winter daily means were then obtained by averaging the 17 calculated fluxes from all combination of inlets (Fig. 3). The daily coefficients of variation (CVs, calculated as the daily standard deviation divided by the daily mean $\times 100$ ) averaged for the whole winter were 30 and $25 \%$ for $\mathrm{NO}_{x}$, and $\mathrm{N}_{2} \mathrm{O}$, respectively, in 2006. In winter $2007 \mathrm{CVs}$ were 19 and $25 \%$ for $\mathrm{NO}_{x}$, and $\mathrm{N}_{2} \mathrm{O}$, respectively. In summer daily means were obtained by averaging the 5 flux measurements obtained by the 5 chambers. The daily CVs, averaged over the whole season, were $\sim 64 \%$, and $139 \%$ for 2006, and 2007, respectively.

Correlations between gas fluxes and selected parameters were carried out using Spearman or Pearson correlation, depending on homogeneity of variances (Levene test). Inter-year variability was tested with one-way ANOVA using daily averages as variables, year as treatment. All statistical analyses were carried out with the software SPSS 12.0 for Windows.
Advection correction

Seok et al. (2009) show how advection from wind pumping reduces not just the gas concentrations in the snowpack, but also gas gradients and consequently fluxes calculated by Eq. 1. Their findings show that at high wind speeds gas transport in the snow is not solely driven by molecular diffusion but that advection can play a substantial role in determining the gas gradients trough the snowpack. From a careful analysis of the dependency of calculated $\mathrm{CO}_{2}$ fluxes on wind speed, it was concluded that, for the wind and snow conditions encountered during a 3-week interval in the middle of the winter, data derived from the diffusion approach underestimated actual fluxes by $36 \%$. The wind conditions encountered during that period appeared to be reasonably representative of the conditions during the 2006 and 2007 winters. Throughout this paper we report fluxes derived from the simplified diffusion approach, in order to be consistent with previous literature and with Liptzin et al. (2009) who used the same approach for $\mathrm{CO}_{2}$ flux. However, in Table 3, we present the larger, corrected flux results for the seasonal and yearly average values, which were derived applying a correction factor of 1.56 as suggested by Seok et al. (2009).

\section{Results and discussion}

Soil nitrogen pools

Pools of soil nitrogen were measured over time during summer 2007 (Table 1). The average nitrate content of $1.3 \mathrm{mg} \mathrm{N} \mathrm{kg}$ dry soil ${ }^{-1}$ and average ammonium content of $\sim 14 \mathrm{mg} \mathrm{N} \mathrm{kg} \mathrm{dry} \mathrm{soil}{ }^{-1}$ are similar to those reported by Williams et al. (1996) and Neff et al. (1994) for the growing season at a nearby dry alpine meadow at Niwot Ridge. Compared to a subalpine meadow soil (Cryorthent) in the European Alps (Freppaz et al. 2007), ammonium content at NWT is similar and nitrate is one order of magnitude lower. The microbial biomass $\left(\mathrm{N}_{\text {microbial }}\right)$ of $102 \mathrm{mg} \mathrm{N} \mathrm{kg} \mathrm{dry} \mathrm{soil}{ }^{-1}$ is similar to the microbial biomass of $110 \mathrm{mg} \mathrm{N} \mathrm{kg} \mathrm{dry} \mathrm{soil}{ }^{-1}$ reported by Fisk and Schmidt (1995) for the Saddle site at Niwot Ridge. Contrastingly, DON of about $50 \mathrm{mg} \mathrm{N} \mathrm{kg} \mathrm{dry}$ soil $^{-1}$ was about four times higher than what was 
Table 1 Soil $\mathrm{N}$ content in summer 2007 at Niwot Ridge (mg kg d.w. ${ }^{-1}$ ) reported by Fisk and Schmidt (1995). These values are indicative of a fast turnover of nitrogen at this site.

\section{Winter results}

Detailed description of meteorological patterns during the winter seasons 2006 and 2007 is provided in Seok et al. (2009). Here we present selected parameters useful to discuss the gaseous $\mathrm{N}$ fluxes. A continuous snowpack developed between the end of October and early November in both years (Fig. 1a). Maximum snow depth was reached on DOY 79 in $2006(194 \mathrm{~cm})$ and DOY 65 in $2007(220 \mathrm{~cm})$. The average air temperature during the snow-covered period was approximately $-5^{\circ} \mathrm{C}$ for both years (Fig. 1b). Air temperature followed approximately the same trend during both winters, with minimum values of about $-22^{\circ} \mathrm{C}$ in mid-winter and an increasing trend in late winter and early spring. Soil surface temperature increased to $\sim 0^{\circ} \mathrm{C}$ in both years when the snowpack reached a depth of approximately $120 \mathrm{~cm}$ (Fig. 1a, c). In winter 2007, when volumetric soil moisture was recorded, there was a small but steady increase in soil moisture starting soon after DOY 1, i.e., coinciding with soil surface temperature warming up to $\sim 0^{\circ} \mathrm{C}$. The gradual increase of liquid water may originate from the snowmelt at the bottom of the snowpack (Feng et al. 2001) or the transport of water vapor from the snowpack to soil because of temperature gradients (Sommerfeld et al. 1996). The gradual increase can also be explained as melting of frost within the first centimeter of soil. Coincident with the main flush of snowmelt starting in early
May, soil volumetric water content increased from about $25 \%$ on DOY 133 to about $60 \%$ by volume on DOY 143 (Fig. 1d).

Concentrations of $\mathrm{N}_{2} \mathrm{O}$ within the snowpack were highest near the ground and decreased with distance from the soil surface (Fig. 2). Concentrations in the snowpack usually linearly decreased with increasing sampling height. Maximum concentrations of $\mathrm{N}_{2} \mathrm{O}$ within the snowpack were near $1,050 \mathrm{ppbv}$ in both years. The multiple inlets allowed us to calculate for each sampling cycle fluxes from nine different combinations of gradient heights in 2006 and from twenty-seven combinations for 2007 (Fig. 3). A detailed analysis on the dependence of concentration gradients on environmental and physical conditions of the snowpack is presented in Seok et al. (2009). Briefly, this work demonstrated that the gradients calculated from within the snowpack were consistently linear, but that a departure from this behavior was observed at the snow-soil, and at the snowatmosphere interface. As with concentrations, $\mathrm{N}_{2} \mathrm{O}$ fluxes calculated between inlets that were close to the snow surface, or close to the soil, deviated more (up to $60 \%$ ) from the average flux than fluxes calculated closer to the center of the snowpack (Fig. 3). The correlation between fluxes from nearby inlets within the snowpack was consistently the highest. To illustrate this behavior, a simple linear regression was applied for fluxes calculated between the 30 and $60-\mathrm{cm}$ inlets and the 60 and 90-cm inlets; results show a correlation with an $R^{2}$ of $0.561(n=1,235$, $p \ll 0.001$ ) and a slope value near one (equation: $y=0.953 x$ ) (Fig. 4). The fact that lower correlations were obtained for fluxes derived from concentration 
Fig. 1 Seasonal course of selected parameters for winters 2006 and 2007. A Snow depth, B Air temperature, C Soil surface temperature, D Soil moisture
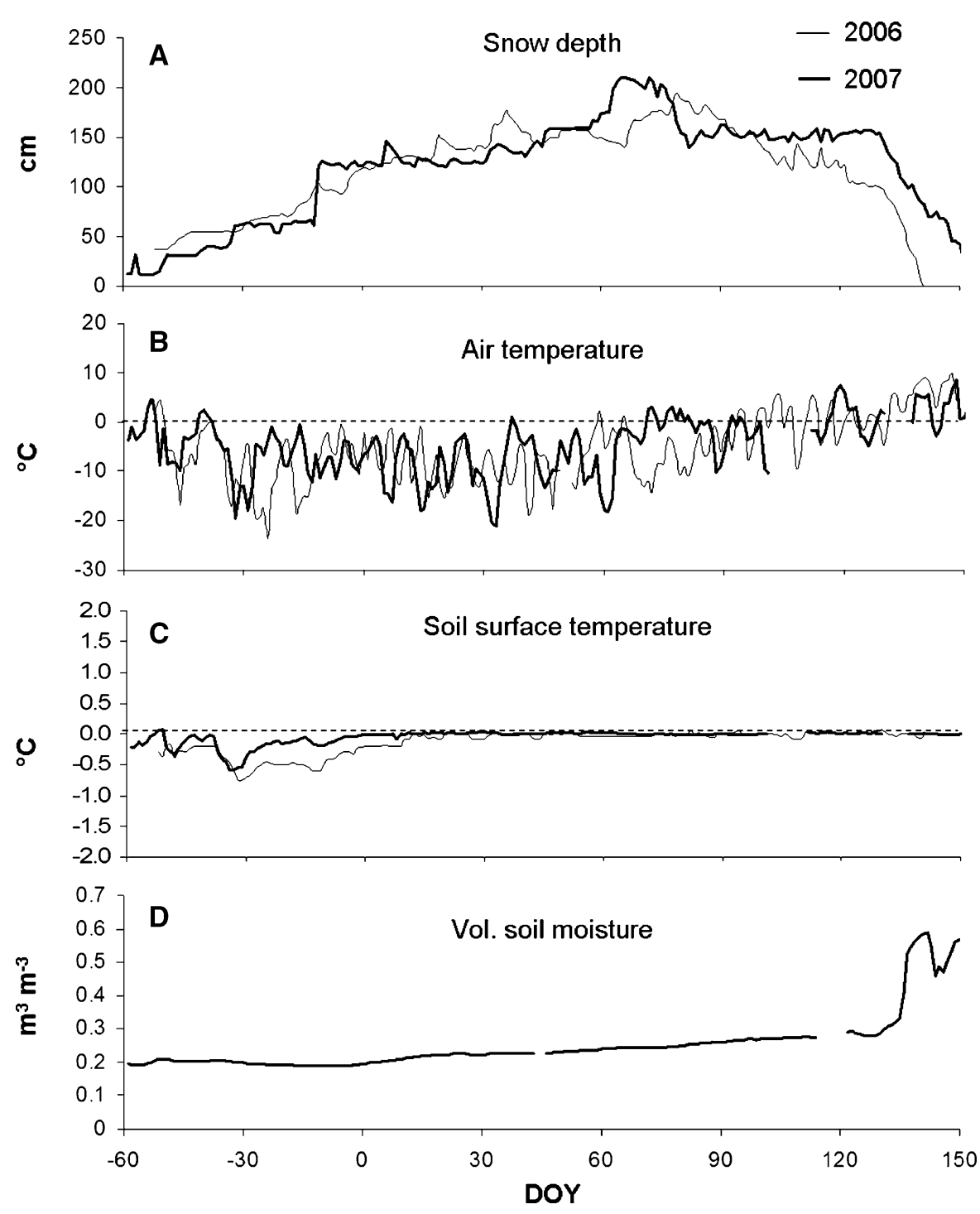

gradients at the snow-atmosphere interface or from measurements near the soil-snow interface or both, and that better correlations were found between fluxes calculated within the snowpack implies that in the center of the snowpack gas transport is well approximated by the diffusion law, without any obvious deviation because of physical barriers such as ice lenses.

For further analyses and interpretations presented in this paper we used the $\mathrm{N}_{2} \mathrm{O}$ flux calculated from inlets at heights of 30 and $60 \mathrm{~cm}$ (Fig. 5). These data were found to generally be in close agreement to the median flux values that were derived from the whole array of flux values calculated from different inlet combinations (Seok et al. 2009). Furthermore, measurements from these heights represented the largest available dataset. For 2006, at the beginning of the winter season fluxes first gradually increased from about 0.020 to $0.090 \mathrm{nmol} \mathrm{m}^{-2} \mathrm{~s}^{-1}$. Fluxes then averaged around $0.080 \mathrm{nmol} \mathrm{m} \mathrm{m}^{-2} \mathrm{~s}^{-1}$, and decreased again during the snowmelt period. In winter 2007, the maximum flux of $\mathrm{N}_{2} \mathrm{O}$ was measured at the initiation of the snowmelt, on DOY 128 (Fig. 5). This peak coincided with the rise in air temperature to above $0^{\circ} \mathrm{C}$, which drove the sharpest snowmelt event of the season (Fig. 1a, b). Shortly after this event, the $\mathrm{N}_{2} \mathrm{O}$ 


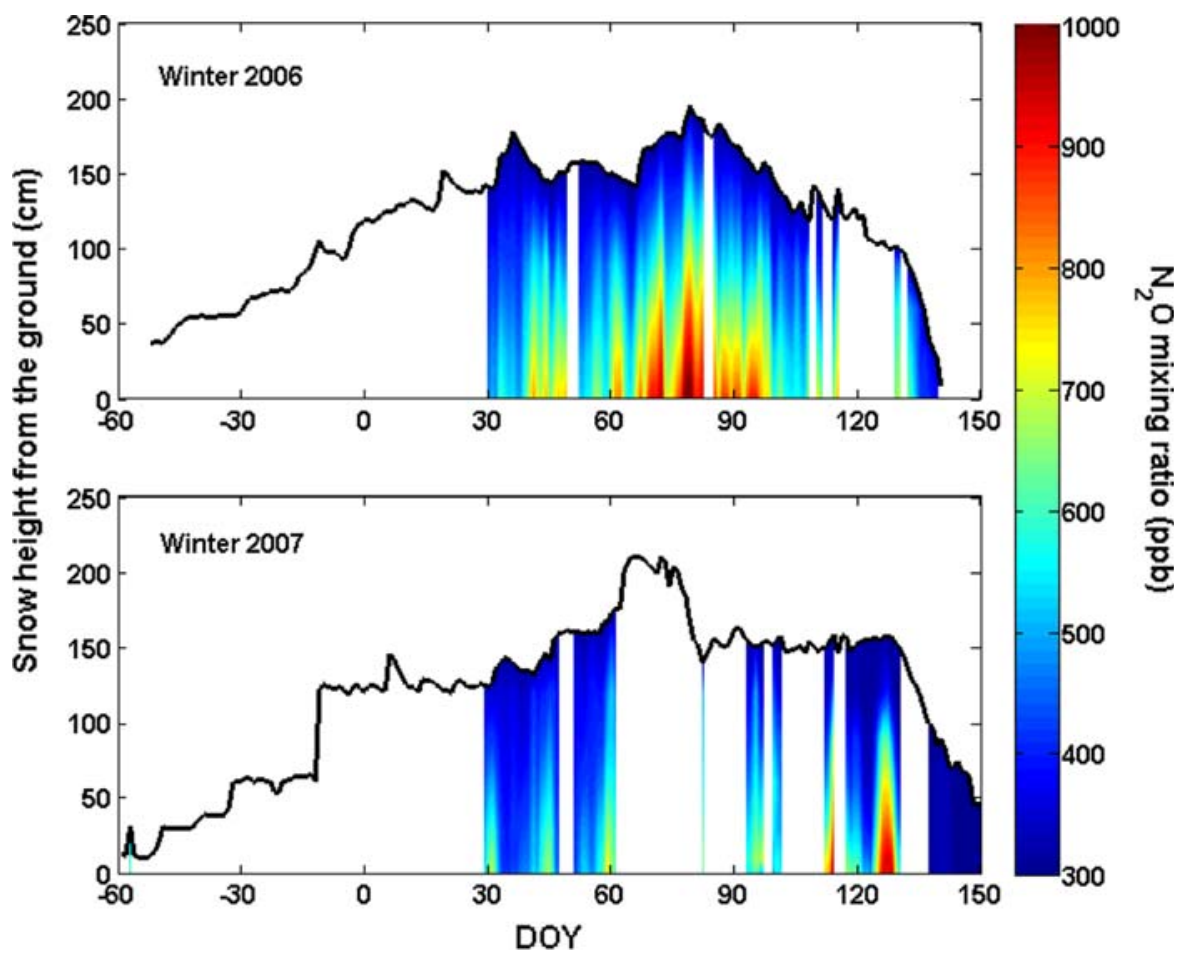

Fig. 2 Contour plots showing $\mathrm{N}_{2} \mathrm{O}$ snowpack interstitial air concentration during the 2006 and 2007 winters. The black line depicts the height of the snowpack

production rapidly decreased to very low values for the rest of the season (i.e., between DOY 140 and 150). Unfortunately, a lack of data during this phase in the winter 2006 record prohibits us from further evaluating the occurrence of such low fluxes during that season (Fig. 5a). The seasonal average $\mathrm{N}_{2} \mathrm{O}$ flux was $0.069 \mathrm{nmol} \mathrm{m}^{-2} \mathrm{~s}^{-1}$ for 2006, and significantly lower in 2007 at $0.047 \mathrm{nmol} \mathrm{m}^{-2} \mathrm{~s}^{-1}(p<0.001)$.

The behavior of $\mathrm{NO}_{x}$ concentrations and fluxes was a bit more complex than for $\mathrm{N}_{2} \mathrm{O}$. At the bottom of the snowpack only NO was observed, but with increasing height an increasing portion of $\mathrm{NO}_{x}$ was in the form of $\mathrm{NO}_{2}$. This feature was interpreted as a portion of $\mathrm{NO}$ converting to $\mathrm{NO}_{2}$, as $\mathrm{NO}$ diffuses from the soil towards the snowpack surface (Helmig et al. 2009). $\mathrm{NO}_{x}$ fluxes were on the order of 0.003$0.007 \mathrm{nmol} \mathrm{m} \mathrm{m}^{-2} \mathrm{~s}^{-1}$, with a slightly decreasing trend towards the end of the winter season, making the $\mathrm{NO}_{x}$ contribution on the order of a fifteenth (on a molar basis) of $\mathrm{N}_{2} \mathrm{O}$ fluxes (Fig. 5). The average $\mathrm{NO}_{x}$ flux during the snow-covered season was significantly higher in 2006 than in 2007 ( $p \ll 0.001$; Table 2).
The statistically higher fluxes of both $\mathrm{N}_{2} \mathrm{O}$ and $\mathrm{NO}_{x}$ in winter 2006 than in 2007, without any obvious difference in surface soil temperature, snowfall timing and depth between the 2 years, suggest that factors other than the parameters recorded here may influence the $\mathrm{N}$ gaseous production under the snow. These factors may include soil moisture (not measured in winter 2006) and the soil nutrient status at the end of the growing season.

Summer results

Summer $\mathrm{N}_{2} \mathrm{O}$ fluxes were studied during the day, typically between 8 am and $4 \mathrm{pm}$. Due to the chamber sampling technique it was not possible to perform night-time measurements, when fluxes are expected to be lower (e.g., Mosier et al. 1997), especially during periods with wide variation in temperature or during rainfalls (Maljanen et al. 2002). Daily fluxes calculated from our dataset are therefore likely to over-estimate the real 24-h average flux. Summer daily fluxes (Fig. 6) ranging from 0.2 to 1.8 
Fig. 3 Seasonal course of daily mean $\mathrm{N}_{2} \mathrm{O}$ fluxes in winters 2006 and 2007, as derived from the available inlet combinations. The solid black line depicts the average of all data

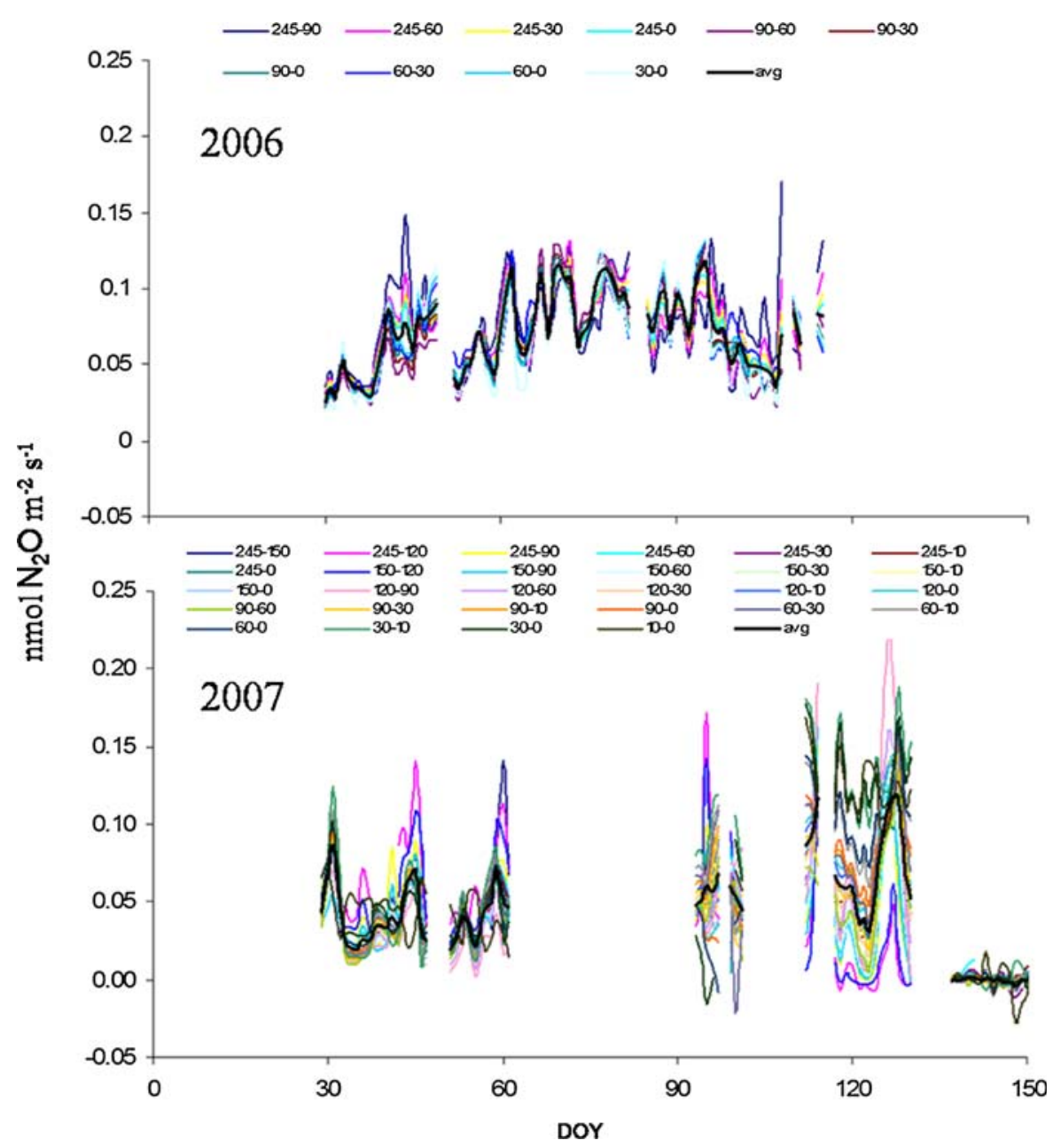

nmol m $\mathrm{m}^{-2} \mathrm{~s}^{-1}$ for 2006 and from -0.1 to $1.1 \mathrm{nmol} \mathrm{m}^{-2} \mathrm{~s}^{-1}$ for 2007 , were about one order of magnitude greater than winter fluxes. Summer fluxes of $\mathrm{N}_{2} \mathrm{O}$ at our site are comparable to the rates reported by Neff et al. (1994) for Niwot Ridge alpine tundra and by Sommerfeld et al. (1993) at a Wyoming subalpine meadow. The summer 2006 $\mathrm{N}_{2} \mathrm{O}$ efflux followed a decreasing trend during the dry-out period. Similarly in 2007 , there was a general trend of decreasing flux over time, with two peaks following high precipitation events interrupting this pattern. The average $\mathrm{N}_{2} \mathrm{O}$ flux of summer 2006 was not statistically different from the summer 2007 flux.

Seasonal $\left(\mathrm{NO}_{x}\right)$ and annual $\left(\mathrm{N}_{2} \mathrm{O}\right)$ budgets

We integrated the fluxes over the whole season by taking the seasonal mean flux, calculated from the daily averages, and multiplied it by the length (in days) of the snow-covered period (200 and 213 days for 2006 and 2007, respectively) and of the snow-free period (158 and 165 days for 2006 and 2007, respectively) to derive a winter and summer budget, respectively. The length of the seasons were calculated based on the first consistent snowfall (i.e., after that event the soil was permanently snow-covered until snowmelt) and by the end of the snowmelt. By integrating the average daily fluxes, we estimated the individual and total $\left(\mathrm{N}_{2} \mathrm{O}+\mathrm{NO}_{x}\right)$ loss for this ecosystem for both winters (Table 2). $\mathrm{N}_{2} \mathrm{O}-\mathrm{N}$ winter losses were 0.34 and $0.24 \mathrm{~kg} \mathrm{~N} \mathrm{ha}^{-1}$ for 2006 and 2007, 30-50 times (on a $\mathrm{N}$ atom basis) that of $\mathrm{NO}_{x}-\mathrm{N}$ winter fluxes at 0.011 and $0.0051 \mathrm{~kg} \mathrm{~N} \mathrm{ha}^{-1}$ for 2006 and 2007.

The estimate of seasonal budgets from a dataset leads to uncertainties, and this is especially the case 
Fig. 4 Scatter plot between 90-60 $\mathrm{cm}$ and 60-30 cm fluxes $\left(\mathrm{nmol} \mathrm{m} \mathrm{m}^{-2} \mathrm{~s}^{-1}\right.$ ), winter 06 . The 1:1 line and the result for the regression equation through all data points are shown
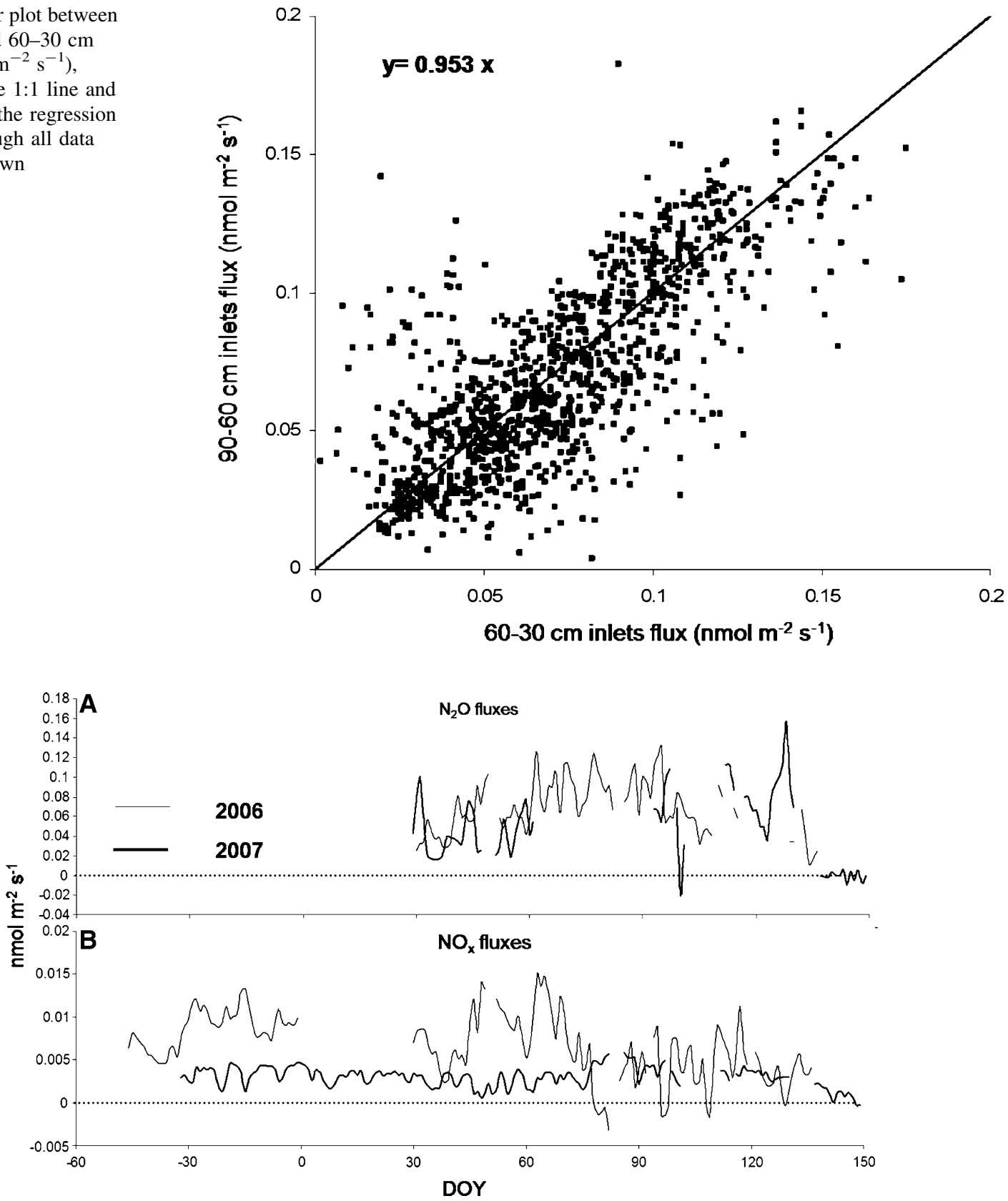

Fig. 5 Seasonal course of mean daily gas fluxes for winters 2006 and 2007 . a $\mathrm{N}_{2} \mathrm{O}$ fluxes (from 60 to $30 \mathrm{~cm}$ inlets), b $\mathrm{NO}_{x}$ fluxes $(60-30 \mathrm{~cm}$ inlets $)$

for data from occasional, non-continuous sampling such as in our summer experiments. Furthermore, about half of our $\mathrm{N}_{2} \mathrm{O}$ winter fluxes were filled in by extrapolation (while the $\mathrm{NO}_{x}$. data set was more continuous), and winter $\mathrm{N}_{2} \mathrm{O}$ fluxes were not determined for the November to January period. In early winter the soil surface temperature is relatively low (compared to the mid winter), which suggests lower $\mathrm{N}_{2} \mathrm{O}$ fluxes. Since we applied an estimate based on the mid to late winter data for that period, this approach may have resulted in an over-estimation of the cumulative winter flux. 
Table 2 Seasonal and annual $\mathrm{N}-\mathrm{N}_{2} \mathrm{O}$ and $\mathrm{N}-\mathrm{NO}_{x}$ loss during years 2006 and 2007

\begin{tabular}{|c|c|c|c|c|c|}
\hline & \multirow[t]{2}{*}{ Source of N } & \multicolumn{2}{|l|}{ Seasonal mean (SE) } & \multirow{2}{*}{$\begin{array}{l}\% \text { of the seasonal } \\
\text { gaseous } \mathrm{N} \text { loss }\end{array}$} & \multirow{2}{*}{$\begin{array}{l}\% \text { of the annual } \\
\mathrm{N}-\mathrm{N}_{2} \mathrm{O} \text { loss }\end{array}$} \\
\hline & & $\mathrm{nmol} \mathrm{m} \mathrm{m}^{-2} \mathrm{~s}^{-1}$ & $\mathrm{~kg} \mathrm{~N} \mathrm{ha}^{-1}$ season & & \\
\hline \multirow[t]{2}{*}{ Winter 06} & $\mathrm{~N}_{2} \mathrm{O}$ & $0.069(0.0033)$ & $0.34(0.015)$ & 97 & \multirow[t]{2}{*}{12} \\
\hline & $\mathrm{NO}_{x}$ & $0.0067(0.00031)$ & $0.011(0.0012)$ & 3 & \\
\hline \multirow[t]{2}{*}{ Summer 06} & $\mathrm{~N}_{2} \mathrm{O}$ & $0.61(0.18)$ & $2.4(0.72)$ & $\mathrm{NE}$ & \multirow[t]{2}{*}{88} \\
\hline & $\mathrm{NO}_{x}$ & $\mathrm{NM}^{\mathrm{a}}$ & NM & & \\
\hline \multirow[t]{2}{*}{ Winter 07} & $\mathrm{~N}_{2} \mathrm{O}$ & $0.047(0.0045)$ & $0.24(0.023)$ & 98 & \multirow[t]{2}{*}{18} \\
\hline & $\mathrm{NO}_{x}$ & $0.0030(0.000094)$ & $0.0051(0.00016)$ & 2 & \\
\hline \multirow[t]{2}{*}{ Summer 07} & $\mathrm{~N}_{2} \mathrm{O}$ & $0.31(0.079)$ & $1.1(0.29)$ & \multirow[t]{2}{*}{$\mathrm{NE}$} & \multirow[t]{2}{*}{82} \\
\hline & $\mathrm{NO}_{x}$ & NM & NM & & \\
\hline
\end{tabular}

The length of the seasons (days) was established according to onset of the snow cover and the end of snowmelt (see text). Winter 2006: 200 days; winter 2007: 213 days; summer 2006: 158 days; summer 2007: 165 days

a Abbreviations: $N M$ not measured, $N E$ not estimated

Our experiment did not include summer measurements of $\mathrm{NO}_{x}$, which limits our ability to assess the total annual oxidized $\mathrm{N}$ balance. Comparing the $\mathrm{N}_{2} \mathrm{O}$ $\mathrm{N}$ loss between winter and following summer we found that winter fluxes account for $\sim 12$ and $18 \%$ of the total $\mathrm{N}_{2} \mathrm{O}$ emitted from this subalpine soil on a yearly basis. When the wind pumping correction is considered the contribution of the winter $\mathrm{N}_{2} \mathrm{O}$ flux increases to $19-28 \%$ of the total annual $\mathrm{N}_{2} \mathrm{O}$ flux.

\section{Comparison with other ecosystems}

The $0.24-0.34 \mathrm{~kg} \mathrm{~N}^{-1}$ of $\mathrm{N}_{2} \mathrm{O}-\mathrm{N}$ flux from our continuous winter measurements at this subalpine meadow is of similar order as the 0.17$0.23 \mathrm{~kg} \mathrm{~N} \mathrm{ha}^{-1}$ that Brooks et al. (1997) report for a much more limited data set from alpine tundra on Niwot Ridge (Table 3). Both the emission rate and the snow depth at our study site were comparable to that of Brooks et al. (1997). Perhaps most importantly, in both studies the soil temperature was about $0^{\circ} \mathrm{C}$ throughout much of the winter because of early-accumulating and deep snowpacks. $\mathrm{N}_{2} \mathrm{O}$ winter fluxes at NWT are in the high range of data reported for forested ecosystems; e.g., our emission rates are comparable to the ones reported by Groffman et al. (2006) and van Bochove et al. (2000) for yellow birch and sugar maple forests (Table 3), which are ecosystems dominated by species associated with high rates of $\mathrm{N}$ cycling (Lovett et al. 2004). Even more surprisingly, $\mathrm{N}_{2} \mathrm{O}$ winter fluxes at NWT are two to threefold higher than for fertilized grasslands in Colorado (Mosier et al. 1997). The relatively well developed soils and the deep snowpack results in prolonged, relatively warm and stable soil temperatures, which may allow the formation of a cold-adapted microbial community (Schadt et al. 2003). The microbial community under the snowpack is phylogenetically and physiologically distinct from that developing during the growing season (Schadt et al. 2003; Monson et al. 2006a, b), and such community can reach its maximum biomass during winter (Brooks et al. 1996; Lipson et al. 2000). This active microbial community has the potential to mineralize nitrogen at high rates (Brooks et al. 1996), providing nitrate supply for denitrification, thus explaining the high emission rates recorded in this study. Supporting our findings, Schürmann et al. (2002) reported a $\mathrm{N}_{2} \mathrm{O}$ efflux as high as $0.5 \mathrm{nmol} \mathrm{m} \mathrm{m}^{-2} \mathrm{~s}^{-1}$ for a fertilized alpine grassland, suggesting that when deep, insulating snowpacks are overlying $\mathrm{N}$-enriched soils, the potential for the $\mathrm{N}_{2} \mathrm{O}$ loss in winter is much higher than during the growing season.

Two previous measurements of $\mathrm{NO}_{x}$ flux from snow-covered soils allow comparison with our data (Maggiotto and Wagner-Riddle 2001; Ludwig et al. 2001). Compared to these reports, NWT $\mathrm{NO}_{x}$ subnivean production is about two-orders of magnitude lower. Moreover, Ludwig et al. (2001) reviewed the current literature on NO emissions from soils, with only two of over 200 studies from tundra and subalpine ecosystems. Most of the $\mathrm{NO}_{x}$ emitted through the snowpack at NWT was in the form of $\mathrm{NO}$, making it possible to compare our winter fluxes 
Fig. 6 Seasonal course of daily $\mathrm{N}_{2} \mathrm{O}$ fluxes for summer 2006 and 2007 (A, error bars are 1SE), volumetric soil moisture for 2007 B and daily precipitation for $2007 \mathbf{C}$

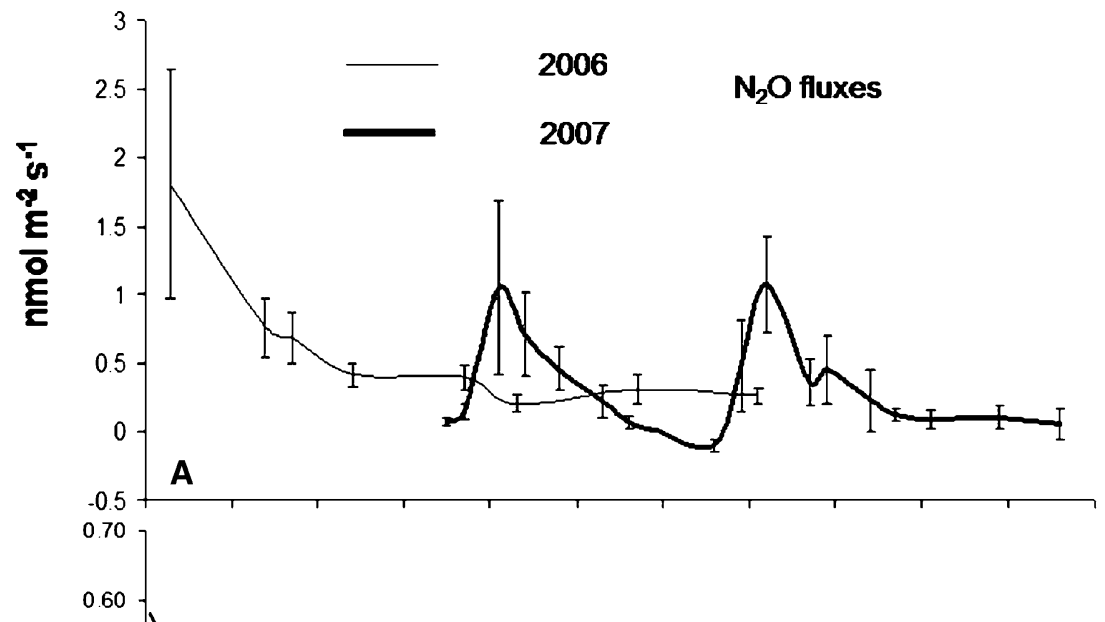

Vol. soil moisture (2007)
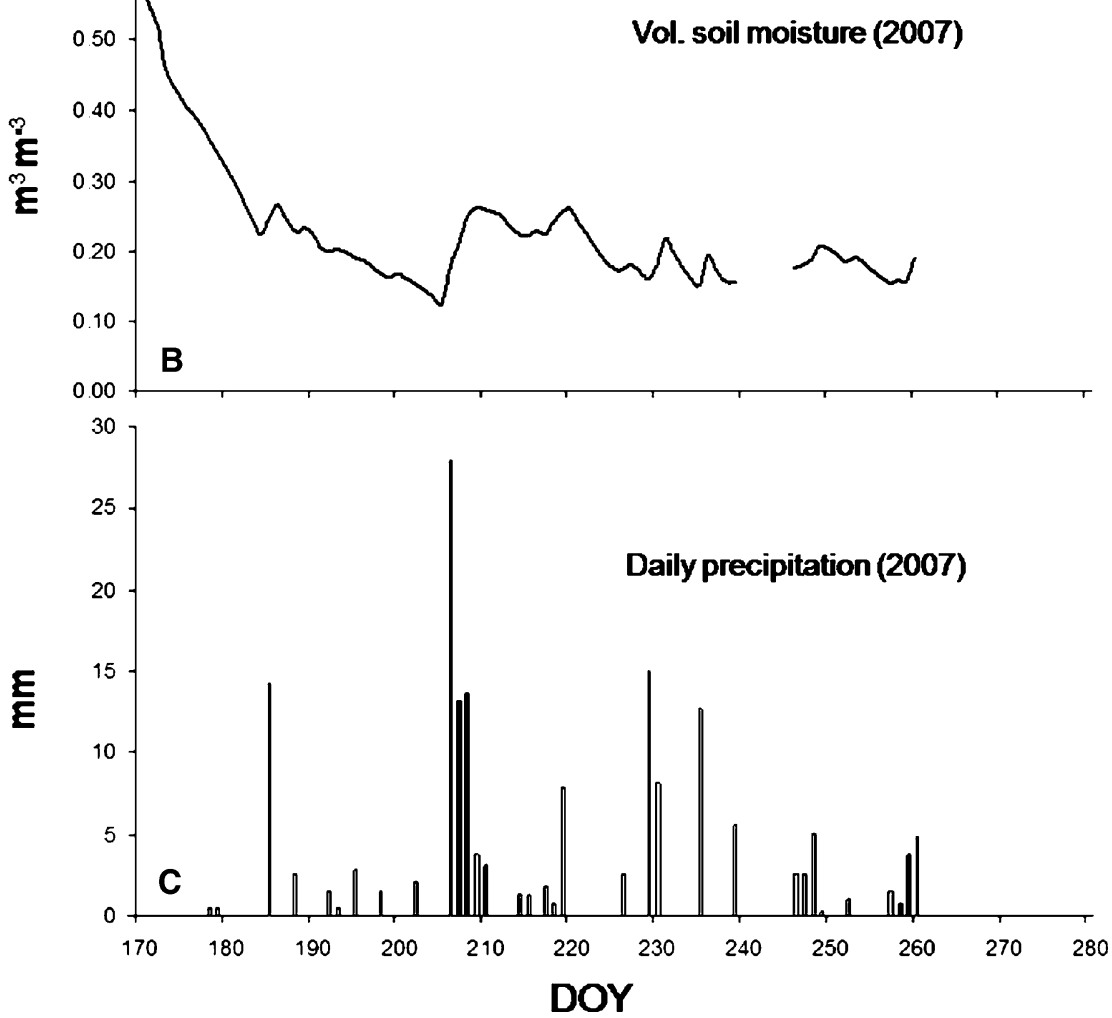

of $\mathrm{NO}_{x}$ with these published data. NWT $\mathrm{NO}_{x}$ flux is roughly comparable to the values reported by Ludwig et al. (2001) for the snow-free season of tundra and subalpine ecosystems, thus confirming that alpine and subalpine snow-covered soils are comparatively weak sources of $\mathrm{NO}_{x}$, but also suggesting that winter production could be as high as the snow-free season production in this ecosystem.
Controls on $\mathrm{N}$ gas fluxes: summer period

During summer, the flux of $\mathrm{N}_{2} \mathrm{O}$ was strongly regulated by precipitation, as shown by several investigators for other ecosystems (Binstock 1984; Sexstone et al. 1985; Neff et al. 1994; Dunfield et al. 1995; Smith et al. 1998; Schürmann et al. 2002). For both summers, there was a general trend of 
Table 3 Comparison of studies that reported $\mathrm{N}_{2} \mathrm{O}$ fluxes in the snow-covered season in different ecosystems

\begin{tabular}{|c|c|c|c|c|c|}
\hline Reference & Site description (abbreviation) & $\begin{array}{l}\text { Mean } \\
\text { annual } \\
\mathrm{T}\left({ }^{\circ} \mathrm{C}\right)\end{array}$ & $\begin{array}{l}\mathrm{N}_{2} \mathrm{O} \text { Flux } \\
\left(\mathrm{nmol} \mathrm{m} \mathrm{m}^{-2} \mathrm{~s}^{-1}\right)\end{array}$ & $\begin{array}{l}\mathrm{kg} \mathrm{N} \mathrm{ha}^{-1} \\
\text { season }^{-1} \\
\text { (for winter) }^{\text {for wing }}\end{array}$ & $\begin{array}{l}\% \text { contribution } \\
\text { to the year } \\
\text { total }\end{array}$ \\
\hline \multirow[t]{2}{*}{ This study } & Subalpine meadow $(\mathrm{NWT})^{\mathrm{a}}$ & -3.7 & $0.047-0.069$ & $0.24-0.34$ & $12-18 \%$ \\
\hline & Corrected for wind pumping effect & & $0.073-0.11$ & $0.38-0.53$ & $19-28 \%$ \\
\hline Brooks et al. (1997) & Alpine Tundra (NWT1) & -3.7 & $0.016-0.046$ & $0.17-0.23$ & n.e. \\
\hline Brooks et al. (1996) & Alpine tundra (NWT2) & -3.7 & $0.026-0.031$ & $\mathrm{NE}$ & NE \\
\hline Sommerfeld et al. (1993) & Subalpine meadow (WY) & -1.0 & $0.006-0.01$ & NE & NE \\
\hline Schürmann et al. (2002) & $\begin{array}{l}\text { Alpine acidic and neutral } \\
\text { pastures (SA) }\end{array}$ & 0.0 & $0.03-0.50$ & $0.01-3.47$ & $5-85 \%$ \\
\hline Zhu et al. (2005) & Antarctic tundra soil (MA) & -20.5 & $0.008-0.013$ & NE & NE \\
\hline van Bochove et al. (2000) & Forested soil (QU1) & 4.2 & $0.033^{*}$ & 0.05 & NE \\
\hline van Bochove et al. (1996) & Forested soil (QU2) & 4.2 & $<0.023$ & $\mathrm{NE}$ & $\mathrm{NE}$ \\
\hline Groffman et al. (2006) & $\begin{array}{l}\text { Forested soil (Sugar maple and } \\
\text { yellow birch) }(\mathrm{NH})\end{array}$ & 4.5 & $0.062-0.087$ & & \\
\hline Kim and Tanaka (2002) & Grassland (HO) & 7.5 & $0-0.004$ & 0.005 & $10 \%$ \\
\hline Maggiotto and Wagner-Riddle (2001) & $\begin{array}{l}\text { Ryegrass fields }(\mathrm{ON}) \\
\quad \text { (control, unfertilized plots) }\end{array}$ & 6.7 & $0-0.09 * *$ & -0.07 & n.e \\
\hline Mosier et al. (1997) & Colorado fertilized grasslands $(\mathrm{CO})$ & 9.3 & $0-0.02$ & $\mathrm{NE}$ & NE \\
\hline Maljanen et al. (2003) & Organic soil (FI) & 2.2 & $0-5.7$ & $\mathrm{NE}$ & $\mathrm{NE}$ \\
\hline
\end{tabular}

Listed data represent the range of the two seasonal mean results for the 2006 and 2007 experiments. For this study, the seasonal and yearly average values, corrected for the wind pumping effect (Seok et al. 2009) are reported, together with the uncorrected data

a Abbreviations: NE not estimated, NWT Niwot Ridge (Colorado), WY Wyoming, SA Swiss Alps $Q U$ Quebec (Canada) $N H$ New Hampshire, $H O$ Hokkaido (Japan), FI Finland, MA Maritime Antarctica, CO Colorado, ON Ontario (Canada)

* Extrapolated from monthly data

** Range extrapolated from graphs

decreasing soil water content after snowmelt associated with a decrease in the flux of $\mathrm{N}_{2} \mathrm{O}$ (Fig. 6). The higher frequency of summer sampling in 2007 was able to capture flux peaks after precipitation events that were two- to threefold higher than background fluxes (Fig. 6). These results are similar to those reported by other researchers who have shown increases in $\mathrm{N}_{2} \mathrm{O}$ flux that usually occur within a few hours to days after precipitation events (Binstock 1984; Sexstone et al. 1985; Neff et al. 1994).

The $\mathrm{N}$ pool in soil is expected to play a role in regulating the $\mathrm{N}_{2} \mathrm{O}$ emissions. Both organic and inorganic nitrogen tend to accumulate in soil in autumn (Table 2). No direct relationship between DIN and $\mathrm{N}_{2} \mathrm{O}$ fluxes was found and perhaps more surprising, summer fluxes of $\mathrm{N}_{2} \mathrm{O}$ were found to be inversely correlated with the DON content of the soil (Fig. 7). Figure 7 shows that as $\mathrm{N}_{2} \mathrm{O}$ fluxes decrease from about $1 \mathrm{nmol} \mathrm{m}^{-2} \mathrm{~s}^{-1}$ to $<0.1 \mathrm{nmol} \mathrm{m}^{-2} \mathrm{~s}^{-1}$, DON doubles from near $30 \mathrm{mg} \mathrm{N} \mathrm{kg} \mathrm{dry} \mathrm{soil}{ }^{-1}$ to over $60 \mathrm{mg} \mathrm{N} \mathrm{kg} \mathrm{dry} \operatorname{soil}^{-1}(r=-0.633, n=8)$.
These results suggest that summer $\mathrm{N}_{2} \mathrm{O}$ efflux decreases as DON is produced. Both plants and microbes may sequester inorganic nitrogen thus reducing available DIN for denitrification process and in turn release $\mathrm{N}$ in organic forms through exudates or cell lyses, respectively, therefore increasing the pool of DON in soil. The lack of correlation between $\mathrm{N}_{2} \mathrm{O}$ fluxes and DIN pool could suggest that the latter undergoes fast transformations in soil (i.e., plant uptake and microbial immobilization) that makes it difficult to track the $\mathrm{N}_{2} \mathrm{O}$ behavior with respect to such labile pool.

Summarizing, these interactions among soil moisture, soil temperature, soil pools of DON and DIN, and $\mathrm{N}_{2} \mathrm{O}$ flux are intriguing but remain partially unexplained, due to the fact that the ecological factors controlling $\mathrm{N}$ gaseous efflux are highly interactive. As a result, the response of $\mathrm{N}_{2} \mathrm{O}$ flux to soil $\mathrm{N}$ appears to be less linear than what was reported in earlier studies (e.g., Skiba et al. 1997; Skiba and Smith 2000; Groffman et al. 2000). 
Fig. 7 Correlation between daily average $\mathrm{N}_{2} \mathrm{O}$ fluxes and dissolved organic nitrogen in topsoil $(0-10 \mathrm{~cm})$ during summer 2007 (Spearman $r$ : -0.633 , $p<0.05)$. Error bars show the standard error
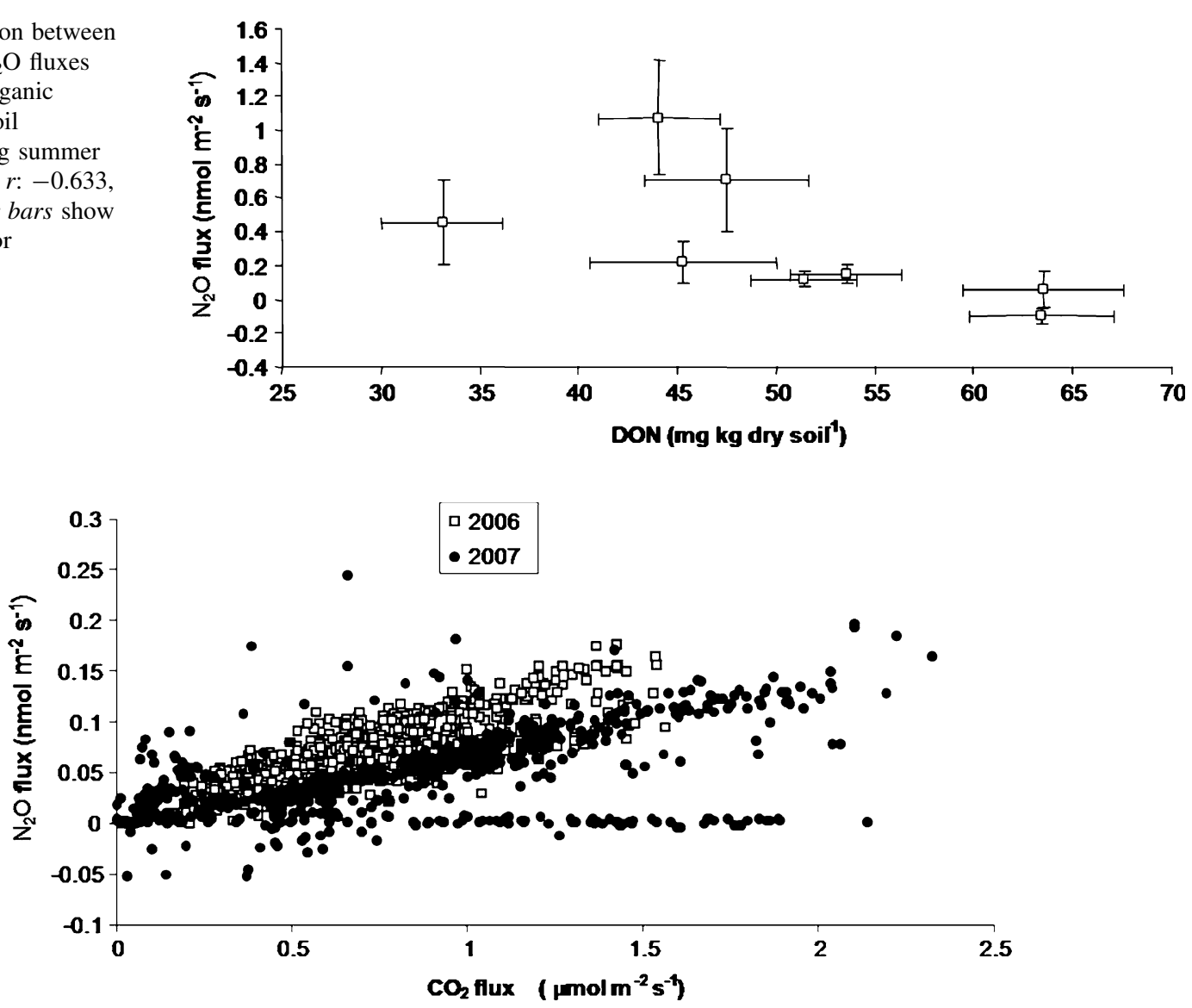

Fig. 8 Correlation between $\mathrm{CO}_{2}$ and $\mathrm{N}_{2} \mathrm{O}$ fluxes (from 60 to $30 \mathrm{~cm}$ inlets) for winter season 2006 and 2007

Controls on $\mathrm{N}$ gas fluxes: winter and snowmelt period

We evaluated whether the winter $\mathrm{N}$ gaseous flux may be related to $\mathrm{CO}_{2}$ production by comparing the fluxes of both gases (Fig. 8). The $\mathrm{CO}_{2}$ fluxes were measured at the same site and are those reported by Liptzin et al. (2009). There was a strong correlation between the $\mathrm{N}_{2} \mathrm{O}$ and $\mathrm{CO}_{2}$ fluxes (Spearman $r=0.806$, $p<0.01)$. However, note that for a portion of the 2007 data set there was little if any flux of $\mathrm{N}_{2} \mathrm{O}$ when fluxes of $\mathrm{CO}_{2}$ remained elevated (Fig. 8). These data resulted from a time period of low fluxes of $\mathrm{N}_{2} \mathrm{O}$ in 2007 during the later stages of snowmelt runoff, i.e., between DOY 140 and 150 (Figs. 3, 5). The high correlation between the two gases during the earlier part of the winter suggests a common source, i.e., that microbially mediated processes are the primary control on both $\mathrm{CO}_{2}$ and $\mathrm{N}_{2} \mathrm{O}$ production. This relationship implies that $\mathrm{CO}_{2}$ production may be primarily from microbial respiration rather than root respiration. A statistically significant correlation was also found between the $\mathrm{CO}_{2}$ and $\mathrm{NO}_{x}$ fluxes (Spearman $r=0.325, p<0.01$ ), and $\mathrm{NO}_{x}$ and $\mathrm{N}_{2} \mathrm{O}$ (Spearman $r=0.342, p<0.01$ ), corroborating the hypothesis that the same environmental parameters are controlling the emission of the three gases.

An ongoing question with respect to trace gas flux through snow is what processes determine the observed flux increases during snowmelt runoff that other investigators have reported during this period (Brooks et al. 1997; Mast et al. 1998; Monson et al. 2006a, b; Sommerfeld et al. 1996). In fact, increases in soil moisture and nitrate concentration during spring snowmelt have been associated with increases in the amount of $\mathrm{N}_{2} \mathrm{O}$ measured (Brooks et al. 1997; Maggiotto and Wagner-Riddle 2001; Maljanen et al. 2007). Consistent with such reports, in winter 2007 
we measured the maximum flux of $\mathrm{N}_{2} \mathrm{O}$ through the snowpack at the initiation of snowmelt. Another mechanism which has been suggested for high $\mathrm{N}_{2} \mathrm{O}$ emission peaks at snowmelt is the release of stored $\mathrm{N}_{2} \mathrm{O}$ from frozen soils (Maljanen et al. 2007); however, the maximum emission recorded in this study occurred when surface soil temperature was close to $0^{\circ} \mathrm{C}$. The fact that the concomitantly determined $\mathrm{CO}_{2}$ flux increased gradually (Liptzin et al. 2009), without showing the rapid increase seen in the $\mathrm{N}_{2} \mathrm{O}$ emission, suggests that biological, rather than physical conditions (which would be expected to exert similar controls on both gases) were the driving factor in the $\mathrm{N}_{2} \mathrm{O}$ behavior.

For the remainder of the snow-covered season (i.e., between DOY 140 and 150 of 2007, Figs. 3 and 5) the production of $\mathrm{N}_{2} \mathrm{O}$ decreased to lower values. This sharp decrease in $\mathrm{N}_{2} \mathrm{O}$ production after the initiation of snowmelt in 2007 is an interesting and unexpected pattern. This drop in $\mathrm{N}_{2} \mathrm{O}$ fluxes causes a remarkable departure from the relationship between fluxes of $\mathrm{N}_{2} \mathrm{O}$ and $\mathrm{CO}_{2}$ (Fig. 8). First, we suspected an artifact in our experiment be responsible for this behavior. Therefore, we carefully re-investigated these data but could not identify any analytical or data processing errors to explain the low amounts of $\mathrm{N}_{2} \mathrm{O}$ flux. Moreover, there was not a similar reduction in our concurrent measurements of the efflux of $\mathrm{CO}_{2}$. This further confirms that an experimental artifact is unlikely, and that sampling problems do not seem adequate to explain this observed decrease in the flux of $\mathrm{N}_{2} \mathrm{O}$. One explanation for the sharp decrease in $\mathrm{N}_{2} \mathrm{O}$ production is that during this period $\mathrm{N}_{2} \mathrm{O}$ production was inhibited by possibly $\mathrm{N}_{2} \mathrm{O}$ being completely reduced to $\mathrm{N}_{2}$. High amounts of soil moisture have been shown to promote the reduction of nitrate to $\mathrm{N}_{2}$, both because of the lower redox potential and the reduced diffusivity of $\mathrm{N}_{2} \mathrm{O}$ in the water-saturated soil, which allows time for the reduction to occur (Chapuis-Lardy et al. 2007). Note that the decrease in $\mathrm{N}_{2} \mathrm{O}$ production after the initiation of snowmelt that we report occurred concurrently with a sharp increase in soil moisture (Fig. 1).

Nutrient limitation (e.g., some combination of carbon and inorganic nitrogen) is another possible reason for this reduction in the measured flux of $\mathrm{N}_{2} \mathrm{O}$ during the later stages of snowmelt. Lipson et al. (2000) have shown that the decline in microbial biomass of soils reported during the snowmelt period (e.g., Brooks et al. 1998; Brooks and Williams 1999; Williams et al. 1996) may be caused by carbon limitation. In particular, longduration, early developing snowpacks such as at our site may promote conditions where the otherwise common pulse of available carbon substrate during snowmelt is reduced (Brooks et al. 1997). The reason is that the long period of time with soils at or near $0^{\circ} \mathrm{C}$ results in an environment where heterotrophic activity may occur throughout the winter, utilizing available nutrients (Brooks and Williams 1999). Moreover, this carbon limitation under the snowpack has been shown to limit microbial respiration rates under snow and the resultant flux of $\mathrm{CO}_{2}$ (Brooks et al. 2005).

Furthermore, after the early stages of snowmelt, inorganic nitrogen could become less available, contributing to the decrease in measured $\mathrm{N}_{2} \mathrm{O}$ flux at this time. Nitrate and ammonium are released from the seasonal snowpack in the form of an ionic pulse (Williams and Melack 1991; Williams et al. 1996). Williams et al. (2009) computed the total $\mathrm{NO}_{3}{ }^{-}-\mathrm{N}$ loading in the snowpack at this site for both years at 1.4-1.7 $\mathrm{kg} \mathrm{N} \mathrm{ha}^{-1}$, a range that exceeds the $\mathrm{N}$ lost as $\mathrm{N}_{2} \mathrm{O}$ by a factor of $5-8$. In addition, the over-winter nitrate production rate through nitrification is considerably high at this site (Brooks et al. 1996). Consequently, nitrate should not be a limiting factor for denitrification. However, Williams et al. (2009) have shown that DON was the dominant form of nitrogen in the soil solution at this site, with concentrations as high as $50 \mu$ moles $\mathrm{L}^{-1}$, and that concentrations of nitrate in nearby surface waters were always negligible. The cause of this discrepancy may be found in the inorganic $\mathrm{N}$ immobilization process: the recovery of isotopically labeled inorganic $\mathrm{N}$ in the soil (Williams et al. 1996) and in plants (Bilbrough et al. 2000) under the snow cover of nearby alpine areas, together with direct evidence of microbial $\mathrm{N}$ immobilization within the soil (Brooks and Williams 1999), suggests that immobilization of inorganic $\mathrm{N}$ in soil is an important control on the retention of $\mathrm{N}$ in the terrestrial environment. Thus, there may have been little nitrate available in underlying soils as a substrate for denitrification processes towards the later stages of snowmelt as a consequence of enhanced $\mathrm{N}$ immobilization and uptake. 


\section{Conclusions}

$\mathrm{N}_{2} \mathrm{O}$ and $\mathrm{NO}_{x}$ efflux from this subalpine meadow soil were detected at significant levels through the snowpack all winter long. Winter $\mathrm{N}_{2} \mathrm{O}$ fluxes at NWT are among the highest ever measured in high elevation ecosystems, and are comparable to those observed in highly productive ecosystems, such as fertilized grasslands and high-N-cycling forests. The relatively well developed soils together with the $\sim 210$ days of prolonged deep snow cover developing at NWT result in subnivean $\mathrm{N}_{2} \mathrm{O}$ production that might account for between 19 and $28 \%$ of the annual flux.

During the summer precipitation was identified as the main factor controlling $\mathrm{N}_{2} \mathrm{O}$ flux. Our data suggest that during winter soil water content and substrate availability determines a $\mathrm{N}_{2} \mathrm{O}$ pulse and subsequent decline during the snowmelt phase. Consequently, the snowmelt period appears to be critical for biological processes in seasonally snowcovered ecosystems.

This investigation on $\mathrm{N}$ gaseous emission through the seasonal snowpack represents an important extension to wintertime trace gas flux research that hitherto has mainly focused on $\mathrm{CO}_{2}$ production. Increasing understanding on $\mathrm{N}_{2} \mathrm{O}$ emission in seasonally snow-covered ecosystems may perhaps fill the gaps that still exist in evaluating the $\mathrm{N}$ budget at a global scale. Moreover, as $\mathrm{N}_{2} \mathrm{O}$ is an important gas in determining the atmospheric radiative forcing, climate change-induced changes in snowpack conditions will likely feedback on wintertime $\mathrm{N}_{2} \mathrm{O}$ flux. Given our current understanding of the controls on the biological processes resulting in $\mathrm{N}_{2} \mathrm{O}$ flux in the wide array of seasonally snow-covered ecosystems, there is still a high uncertainty with both the direction and the magnitude of potential changes in these fluxes in a changing climate.

Acknowledgments Research at NWT has been funded by a Long-Term Ecological Research grant from the National Science Foundation (award \# NSF DEB0423662) and by NSF grant OPP-0240976. Field research activities by Gianluca Filippa were supported by a scholarship from the University of Torino, Di.Va.P.R.A.-Agrochemistry and Pedology, and INSTAAR. Any opinions, findings, and conclusions expressed in this material are those of the authors and do not necessarily reflect the views of NSF. We thank Christine M. Seibold for laboratory soil analyses and Luisella Celi for valuable revisions and helpful discussions on the manuscript.
Open Access This article is distributed under the terms of the Creative Commons Attribution Noncommercial License which permits any noncommercial use, distribution, and reproduction in any medium, provided the original author(s) and source are credited.

\section{References}

Alm J, Saarnio S, Nykanen H, Silvola J, Martikainen PJ (1999) Winter $\mathrm{CO}_{2}, \mathrm{CH}_{4}$ and $\mathrm{N}_{2} \mathrm{O}$ fluxes on some natural and drained peatlands. Biogeochemistry 44:163-199. doi: 10.1023/A:1006074606204

Bilbrough CJ, Welker JM, Bowman WD (2000) Early Spring nitrogen uptake by snow-covered plants: a comparison of arctic and alpine plant function under the snowpack. Arct Antarct Alp Res 32(4):404-411. doi:10.2307/1552389

Binstock DA (1984) Potential denitrification in an acid forest soil: dependence on wetting and drying. Soil Biol Biochem 16(3):287-288. doi:10.1016/0038-0717(84)90019-1

Bowden WB (1986) Gaseous nitrogen emissions from undisturbed terrestrial ecosystems: an assessment of their impacts on local and global nitrogen budgets. Biogeochemistry 2:249-279. doi:10.1007/BF02180161

Bowling DR, Massman WJ, Schaeffer SM, Burns SP, Monson RK, Williams MW (2009) Biological and physical influences on the carbon isotope content of $\mathrm{CO}_{2}$ in a subalpine forest snowpack, Niwot Ridge, Colorado. Biogeochemistry. doi:10.1007/s10533-008-9233-4

Brookes PC, Landman A, Pruden G, Jenkinson DS (1985) Chloroform fumigation and the release of soil nitrogen. A rapid direct extraction method to measure microbial biomass nitrogen in soil. Soil Biol Biochem 17:837-842. doi: 10.1016/0038-0717(85)90144-0

Brooks PD, Williams MW (1999) Snowpack controls on nitrogen cycling. Hydrol Process 13:2177-2190

Brooks PD, Schmidt SK, Williams MW (1995) Snowpack controls on soil nitrogen dynamics in the Colorado alpine. In: Tonnessen K, Williams M, Tranter M (eds) Biogeochemistry of snow covered catchments. International Association of Hydrological Sciences Publication 228, Wallingford, pp 283-292

Brooks PD, Williams MW, Schmidt SK (1996) Microbial activity under alpine snowpacks, Niwot Ridge, Colorado. Biogeochemistry 32:93-113. doi:10.1007/BF00000354

Brooks PD, Schmidt SK, Williams MW (1997) Winter production of $\mathrm{CO}_{2}$ and $\mathrm{N}_{2} \mathrm{O}$ from alpine tundra: environmental controls and relationship to inter-system $\mathrm{C}$ and $\mathrm{N}$ fluxes. Oecologia 110:403-413

Brooks PD, Williams MW, Schmidt SK (1998) Inorganic nitrogen and microbial biomass dynamics before and during spring snowmelt. Biogeochemistry 43:1-15. doi: 10.1023/A: 1005947511910

Brooks PD, McKnight D, Elder K (2005) Carbon limitation of soil respiration under winter snowpacks: potential feedbacks between growing season and winter carbon fluxes. Glob Chang Biol 11:231-238. doi:10.1111/j.1365-2486.2004. 00877.x

Burns SF (1980) Alpine soil distribution and development, Indian Peaks, Colorado Front Range. Ph.D. Dissertation, University of Colorado, Boulder 
Caine N (1995) Temporal trends in the quality of streamwater in an alpine environment: Green Lakes Valley, Colorado Front Range, USA. Geogr Ann Ser B Hum Geogr 77A:207-220. doi:10.2307/521330

Chapuis-Lardy L, Wrage N, Metay A, Chotte J, Bernoux M (2007) Soils, a sink for $\mathrm{N}_{2} \mathrm{O}$ ? A review. Glob Change Biol 13(1):1-17. doi:10.1111/j.1365-2486.2006.01280.x

Delmas R, Serca D, Jambert C (1997) Global inventory of $\mathrm{NO}_{X}$ sources. Nutr Cycl Agroecosyst 48:51-60. doi:10.1023/ A: 1009793806086

Dunfield PF, Topp CH, Knowles R (1995) Effect of nitrogen fertilizers and moisture content on $\mathrm{CH}_{4}$ and $\mathrm{N}_{2} \mathrm{O}$ fluxes in a humisol: measurements in the field and intact soil cores. Biogeochemistry 29:199-222. doi:10.1007/BF02186048

Feng XH, Kirchner JW, Renshaw CE, Osterhuber RS, Klaue B, Taylor S (2001) A study of solute transport mechanisms using rare earth element tracers and artificial rainstorms on snow. Water Resour Res 37:1425-1435. doi:10.1029/ 2000WR900376

Fisk MC, Schmidt SK (1995) Nitrogen mineralization and microbial biomass $\mathrm{N}$ dynamics in three alpine tundra communities. Soil Sci Soc Am J 59:1036-1043

Freppaz M, Williams BL, Edwards AC, Scalenghe R, Zanini E (2007) Simulating soil freeze/thaw cycles typical of winter alpine conditions: implications for $\mathrm{N}$ and $\mathrm{P}$ availability. Appl Soil Ecol 35:247-255. doi:10.1016/j.apsoil. 2006.03.012

Groffman PM, Brumme R, Butterbach-Bahl K, Dobbie K, Mosier AR, Ojima DS, Papen H, Parton WJ, Smith KA, Wagner-Riddle C (2000) Evaluating annual nitrous oxide fluxes at the ecosystem scale. Global Biogeochem Cycles 14:1061-1070. doi:10.1029/1999GB001227

Groffman PM, Hardy JP, Driscoll CT, Fahey T (2006) Snow depth, soil freezing, and fluxes of carbon dioxide, nitrous oxide and methane in a northern hardwood forest. Glob Change Biol 12:1748-1760. doi:10.1111/j.1365-2486.2006. 01194.x

Helmig D, Seok B, Hueber J, Sanford R Jr, Williams M (2009) Fluxes and chemistry of nitrogen oxides in the Niwot Ridge, Colorado, snowpack. Biogeochemistry. doi: 10.1007/s10533-009-9312-1

Intergovernmental Panel on Climate Change (2001) Climate Change. The IPCC third assessment report. Cambridge University Press, Cambridge and New York. Vols. I (The scientific basis), II (Impacts) and III (Socioeconomic implications)

Jones HG, Pomeroy JW, Davies TD et al (1999) $\mathrm{CO}_{2}$ in Arctic snow cover: landscape form, in-pack gas concentration gradients, and the implications for the estimation of gaseous fluxes. Hydrol Process 13:2977-2989

Kim Y, Tanaka N (2002) Winter $\mathrm{N}_{2} \mathrm{O}$ emission rate and its production rate in soil underlying the snowpack in a subboreal region, Japan. J Geophys Res 107(D19):4406. doi:10.1029/2001JD000833

Lipson DA, Schmidt SK, Monson RK (2000) Carbon availability and temperature control the post-snowmelt decline in alpine soil microbial biomass. Soil Biol Biochem 32:441-448. doi:10.1016/S0038-0717(99)00068-1

Liptzin D, Helmig D, Williams MW, Seok B, Filippa G, Chowanski K, Hueber J (2009) Process-level controls on $\mathrm{CO}_{2}$ fluxes from a seasonally snow-covered subalpine meadow soil, Niwot Ridge, Colorado. Biogeochemistry. doi:10.1007/s10533-009-9303-2

Lovett GM, Weathers KC, Arthur MA, Schultz JC (2004) Nitrogen cycling in a northern hardwood forest: do species matter? Biogeochemistry 67:289-308. doi: 10.1023/B:BIOG.0000015786.65466.f5

Ludwig J, Meixner FX, Vogel B, Förstner J (2001) Soil-air exchange of nitric oxide: an overview of processes, environmental factors, and modeling studies. Biogeochemistry 52:225-257. doi:10.1023/A:1006424330555

Maggiotto SR, Wagner-Riddle C (2001) Winter and spring thaw measurements of $\mathrm{N}_{2} \mathrm{O}$, $\mathrm{NO}$ and $\mathrm{NO}_{x}$ fluxes using a micrometeorological method. Water Air Soil Pollut Focus 1:89-98. doi:10.1023/A:1013174214957

Maljanen M, Martikainen PJ, Aaltonen H, Jouko S (2002) Short-term variation in fluxes of carbon dioxide, nitrous oxide and methane in cultivated and forested organic boreal soil. Soil Biol Biochem 34:577-584. doi: 10.1016/S0038-0717(01)00213-9

Maljanen M, Liikanen A, Silvola J, Martikainen PJ (2003) Measuring $\mathrm{N}_{2} \mathrm{O}$ emissions from organic soils by closed chamber or soil/snow $\mathrm{N}_{2} \mathrm{O}$ gradient methods. Eur J Soil Sci 54:625-631. doi:10.1046/j.1365-2389.2003.00531.x

Maljanen M, Khonen RA, Virkajarvi P, Martikainen PJ (2007) Fluxes and production of $\mathrm{N}_{2} \mathrm{O} \mathrm{CO}_{2}$ and $\mathrm{CH}_{4}$ in boreal agricultural soil during winter as affected by snow cover. Tellus 59B:853-859

Martikainen PJ, Nykanen H, Crill P, Silvola J (1993) Effect of a lowered water table on nitrous oxide fluxes from northern peatlands. Nature 366:51-53. doi:10.1038/ $366051 \mathrm{a} 0$

Massman WJ (1998) A review of the molecular diffusivities of $\mathrm{H}_{2} \mathrm{O} \mathrm{CO} \mathrm{CO}_{2}, \mathrm{CH}_{4}, \mathrm{CO}, \mathrm{O}_{3}, \mathrm{SO}_{2}, \mathrm{NH}_{3}, \mathrm{~N}_{2} \mathrm{O}, \mathrm{NO}$, and $\mathrm{NO}_{2}$ in air, $\mathrm{O}_{2}$ and $\mathrm{N}_{2}$ near STP. Atmos Environ 32:1111-1127. doi:10.1016/S1352-2310(97)00391-9

Mast MA, Wickland KP, Striegl RT, Clow DW (1998) Winter fluxes of $\mathrm{CO}_{2}$ and $\mathrm{CH}_{4}$ from subalpine soils in Rocky Mountain National Park, Colorado. Global Biogeochem Cycles 12:607-620. doi:10.1029/98GB02313

Monson RK, Lipson DA, Burns SP, Turnipseed AA, Delany AC, Williams MW, Schmidt SK (2006a) Winter forest soil respiration controlled by climate and microbial community composition. Nature 439:711-714. doi:10.1038/nature04555

Monson RK, Burns SP, Williams MW et al (2006b) The contribution of beneath-snow soil respiration to total ecosystem respiration in a high-elevation, subalpine forest. Global Biogeochem Cycles 20:GB3030. doi: 10.1029/2005GB002684

Mosier AR, Delgado JA, Cochran VL, Valentine DW, Parton WJ (1997) Impact of agriculture on soil consumption of atmospheric $\mathrm{CH}_{4}$ and a comparison of $\mathrm{CH}_{4}$ and $\mathrm{N}_{2} \mathrm{O}$ flux in subarctic, temperate and tropical grasslands. Nutr $\mathrm{Cycl}$ Agroecosyst 49:71-83. doi:10.1023/A:1009754207548

Neff JC, Bowman WD, Holland EA, Fisk MC, Schmidt SK (1994) Fluxes of nitrous oxide and methane from nitrogen-amended soils in a Colorado alpine ecosystem. Biogeochemistry 27:23-33. doi:10.1007/BF00002569

Schadt CW, Martin AP, Lipson DA, Schmidt SK (2003) Seasonal dynamics of previously unknown fungal lineages in tundra soils. Science 301:1359-1361. doi:10.1126/science. 1086940 
Schürmann A, Mohn J, Bachofen R (2002) $\mathrm{N}_{2} \mathrm{O}$ emissions from snow-covered soils in the Swiss Alps. Tellus 54B:134-142

Seok B, Williams MW, Helmig D, Liptzin D, Chowanski K, Hueber J (2009) An automated system for continuous measurements of trace gas fluxes through snow: an evaluation of the gas diffusion method at a subalpine forest site, Niwot Ridge, Colorado. Biogeochemistry. doi: 10.1007/s10533-009-9302-3

Sexstone AJ, Parkin TB, Tiedje JM (1985) Temporal response of soil denitrification rates to rainfall and irrigation. Soil Sci Soc Am J 49:99-103

Skiba U, Smith KA (2000) The control of nitrous oxide emissions from agricultural and natural soils. Chemosphere 2:379-386

Skiba U, Fowler D, Smith KA (1997) Nitric oxide emissions from agricultural soils in temperate and tropical climates: source, control and mitigation options. Nutr Cycl Agroecosyst 48:75-90. doi:10.1023/A:1009734514983

Smith KA, Thomson PE, Clayton H, McTaggart IP, Conen F (1998) Effects of temperature, water content and nitrogen fertilization on emissions of nitrous oxide by soils. Atmos Environ 32:3301-3309. doi:10.1016/S1352-2310(97)00492-5

Sommerfeld RA, Mosier AR, Musselman RC (1993) $\mathrm{CO}_{2}, \mathrm{CH}_{4}$ and $\mathrm{N}_{2} \mathrm{O}$ flux through a Wyoming snowpack and implications for global budgets. Nature 361:140-142. doi: 10.1038/361140a0

Sommerfeld RA, Massman WJ, Musselman RC, Mosier AR (1996) Diffusional flux of $\mathrm{CO}_{2}$ through snow: spatial and temporal variability among alpine-subalpine sites. Global Biogeochem Cycles 10:473-482. doi:10.1029/96GB01610
Van Bochove E, Jones GH, Pelletier F, Prevost D (1996) Emission of $\mathrm{N}_{2} \mathrm{O}$ from agricultural soil under snow cover: a significant part of $\mathrm{N}$ budget. Hydrol Process 10:1545-1549. doi: 10.1002/(SICI)1099-1085(199611)10:11<1545::AID-HYP 492>3.0.CO;2-0

Van Bochove E, Jones GH, Bertrand N, Prevost D (2000) Winter fluxes of greenhouse gases from snow-covered agricultural soil: intra-annual and inter-annual variations. Global Biogeochem Cycles 14:113-125. doi:10.1029/ 1999GB900101

Welles JM, Demetiades-Shah TH, McDermitt DK (2001) Consideration for measuring ground $\mathrm{CO}_{2}$ effluxes with chambers. Chem Geol 177:3-13. doi:10.1016/S0009-2541(00) 00388-0

Williams MW, Melack JM (1991) Precipitation chemistry in and ionic loading to an Alpine Basin, Sierra Nevada. Water Resour Res 27(7):1563-1574. doi:10.1029/ 90WR02773

Williams MW, Brooks PD, Mosier A, Tonnessen KA (1996) Mineral nitrogen transformations in and under seasonal snow in a high-elevation catchment in the Rocky Mountains, USA. Water Resour Res 32(10):3161-3171. doi: 10.1029/96WR02240

Williams MW, Seibold C, Chowanski K (2009) Storage and release of solutes from a seasonal snowpack: soil and stream water response, Niwot Ridge, Colorado. Biogeochemistry. doi:10.1007/s10533-009-9288-x

Zhu R, Sun L, Ding W (2005) Nitrous oxide emissions from tundra soil and snowpack in the maritime Antarctic. Chemosphere 59:1667-1675. doi:10.1016/j.chemosphere.2004.10.033 